\title{
THE PFIZER REASONABLE BASIS TEST-FAST RELIEF FOR CONSUMERS BUT A HEADACHE FOR ADVERTISERS
}

In Pfizer, Inc., ${ }^{1}$ the Federal Trade Commission (FTC) warned that any advertising claim made without a "reasonable basis" or prior substantiation would violate section 5 of the Federal Trade Coinmission Act, ${ }^{2}$ "[w] hether or not the claim [was] true and the product performed as advertised . $\therefore$. The Pfizer opinion clearly indicates that henceforth the FTC not only will respond to consumer complaints of falsity and fraud, but also will affirmatively challenge unsubstantiated claims as an advertising method harmful to consumers. Since the summer of 1971 , the FTC has required substantiation briefs from major advertisers. ${ }^{4}$ Upon examining this required

1. 3 Trade REg. ReP. If 20,056 , at 22,029 (FTC July 11, 1972).

HEREINAFTER THE FOLLOWING CITATIONS WILL BE USED IN THIS NOTE:

J. Bishop \& H. Hubbard, Let the Selier Beware (1969) thereinafter cited as BISHOP];

E. Cox, R. Felimeth \& J. Schulz, "The Nader Report" on the Federal TRADE COMMISSION (1969) [hereinafter cited as NADER REPORT];

ABA, Report of the Commission To Study the Federal Trade Commission (1969) [hereinafter cited as ABA REPORT];

Travers, Foreward to Symposium: Federal Trade Commission Regulation of Deceptive Advertising, 17 U. KAN. L. REv. 551 (1969) [hereinafter cited as Travers];

Interview with Robert Pitofsky, Director of FTC Bureau of Consumer Protection, reprinted in 595 BNA ANTITRUST \& TRADE REG. REP. AA-1 (1973) [hereinafter cited as Pitofsky Interview].

2. 15 U.S.C. $\S 45$ (a)(1) (1970). The most important provision of the Act relevant to consumer protection states: "Unfair methods of competition in commerce, and unfair or deceptive acts or practices in commerce, are declared unlawful." Id.

3. Pfizer, Inc., 3 Trade REg. ReP. II 20,056, at 22,029 (FTC July 11, 1972) (emphasis added).

4. Section 6 of the Federal Trade Commission Act, 15 U.S.C. $\S 46$ (1970), grants additional powers to the FTC, including authority to investigate and compile information concerning the organization or practices of any corporation, to require corporations to furnish written reports in answer to written questions, and to publicize at the FT.C's discretion any available information with the exception of trade secrets and the names of customers.

The broad investigational role of the FTC in other than antitrust cases has frequently been upheld. See, e.g., Umited States v. Morton Salt Co., 338 U.S. 632 (1950); United States v. National Biscuit Co., 25 F. Supp. 329 (S.D.N.Y. 1938) (although the Commission was empowered to issue a questionnaire to defendantcompany, the FTCA did not authorize penalties for defendant's failure to answer the questionnaire). 
documentation, the Commission recently issued its first formal complaints based on Pfizer, ${ }^{5}$ transforming the primarily investigative substantiation program into a potentially powerful enforcement tool.

The new aggressiveness of the FTC stands in marked contrast to the Commission's previous "portrait of impotence" in consumer protection. For over fifty years, the FTC, underfunded, misdirected, and demoralized, ${ }^{7}$ struggled with infrequent success against consumer fraud. ${ }^{8}$ Numerous theories have been offered to explain the FTC's ineffectiveness, ${ }^{9}$ and some critics have even advocated abol-

5. See notes 100-01 infra and accompanying text.

6. NADER REPORT 68. The investigating group suggested that behind the FTC's past impotence may have been a "powerlessness with a purpose." Id. This purpose was viewed as favoritism for "big business and Congressional interests." Id. at 38-39.

7. ABA REPORT 34-37.

The two recurring criticisms of the FTC ... - -failure to plan and the crippling delay in its procedures-are about as serious today as at any time in the agency's history. .... M] $t$ is our impression that there are too many instances of incompetence in the agency, particularly in senior staff positions. Additional aspects of recent FTC performance are also disturbing. Under-allocation of resources for consumer protection ... [ [has] sapped the FTC's effectiveness in critical areas of its responsibility ..... Congress is partly responsible for the FTC's problems because of its practice of committing important new legislative programs to the agency without commensurate increases in budget. [However, we] also conclude that the FTC

has not done what it could with the resources that have been available to

it. Id. at 34 .

8. A notable exception was the strikingly effective FTC crusade against cigarette advertising and labeling. See Unfair or Deceptive Advertising and Labeling of Cigarettes in Relation to the Health Hazards of Smoking, 16 C.F.R. $\S 408$ (1973) (trade regulation rule). For a critical analysis of the anti-smoking campaigns of the FTC and FCC and first amendment implications, see Redish, The First Amendment in the Marketplace: Commercial Speech and the Values of Free Expression, 39 GEO. WASH. L. REV. 429, 464-68 (1971).

9. Limited resources have been a major problem for the FTC. Compare NADER REPORT 87, 225 with Letter from FTC Chairman Miles Kirkpatrick to Senator Lee Metcalf, reprinted in part in 564 BNA ANTITRUST \& TRADE REo. ReP. A-15 (1972). Although appropriations have doubled since 1968, almost one-half of the funds are allocated to antitrust enforcement. See generally ABA REPORT 26-27. The Bureau of Consumer Protection Budget is still dwarfed by the combined television advertising budgets of the makers of such major products as "Anacin" and "Bayer Aspirin." NADER REPORT 22-23; Travers 556.

According to oue observer, the powerful role in the economy of the inherently deceptive advertising industry necessarily reduces the FTC to a "cosmetic operation." Id. at 558. For a general discussion of how consumer purchasing motives encourage deception, see J. Galbraith, THE New Industrial State 325-53 (1967). See also Charlton \& Fawcett, The FTC and False Advertising, 17 U. KaN. L. Rev. 599, 601 (1969).

The opposition of powerful business interests may also have contributed to the Commission's ineffectiveness. See Thain, Consumer Protection: AdvertisingThe FTC Response, 26 FoOd Drug CoSM. L.J. 609, 625 (1971); cf. STAFF of Subcomm. on Consumers of Senate Comm. on Commerce, 92d Cong., 2d Sess., Report ON INITIATIVES IN CORPORATE REsponsibility, reprinted in part in 
ishing the FTC altogether. ${ }^{10}$ The FTC, however, not only has survived the blistering criticism of the late 1960's, but recently has plunged into new areas of regulation. Advertisers have understandably viewed this developinent with disinay, as the "tigers of the FTC"11 become more and more the "omnipresent overseer[s] of a corporation's day-to-day activities."12 In addition to this vigorous surge of consumer protectiomsm, the FTC has fashioned imagimative and innovative orders to effectuate its new policies. ${ }^{13}$ By fram-

582 BNA ANTITrust \& Trade Reg. Rep. E-1 (1972) (listing business accomplishments in the field of consumer protection to "balance the record").

Within the Commission itself, the lack of planning and positive leadership and the unwillingness to depart from traditional, ineffective enforcement procedures were in great part responsible for the skepticism with which the FTC was viewed. See ABA REPORT 3, 53; NADER REPORT 39.

The courts themselves have often been hostile to the FTC's consumer protection role. See, e.g., FTC v. Raladam Co., 283 U.S. 643 (1931); Sperry \& Hutchinson Co. v. FTC, 432 F.2d 146 (5th Cir. 1970), rev'd, 405 U.S. 233 (1972); ABA REPORT 53; Comment, Section 5 of the Federal Trade Commission Act: A Source of Protection for Competitors and Consumers, 12 B.C. IND. \& CoM. L. REV. 982, 992 (1971).

10. E.g., ABA REPORT 92-93, 104-05 (separate statement of Professor Richard Posner).

11. 552 BNA ANtTtrust \& Trade Reg. Rep. A-31 (1972) (cautious approval of the new regulation given by Earl Kintner, former FTC Chairman).

Rumors surrounding the resignation of activist FTC Chairman Kirkpatrick, former cliairman of the commission which authored the ABA REPORT, see Address by Senator Moss, reprinted in 582 BNA ANTTTRUST \& TrADE REg. REP. A-6 (1972), were quieted by the belief of insiders that his successor would follow through with the many controversial programs now in operation. Address by Robert Pitofsky, reprinted in part in 581 BNA ANTTrRUST \& TRADE REg. REP. A-2 (1972); see Pitofsky Interview AA-5.

12. N.Y.L.J., Oct. 27, 1972, at 5, col. 1 (statements before the ABA National Institute on "Corporations Under Attack-Response to New Challenges").

Courts have not expected advertising to offer an objective appraisal of pertinent information and hence have previously tolerated a substantial amount of trade "puffing." iSee, e.g., Lambert v. Sistunk, 58 So. 2d 434 (Fla. 1952); Prince v. Brackett, Shaw \& Lunt Co., 125 Me. 31, 130 A. 509 (1925); Brown v. Globe Labs, Inc., 165 Neb. 138, 84 N.W.2d 151 (1957); American Laundry Mach. Co. v. Skinner, 225 N.C. 285, 34 S.E.2d 190 (1945); Maupin v. Nutrena Mills, Inc., 385 P.2d 504 (Okla. 1963). However, the scope of the FTC's recent efforts corresponds with the intensity of other important restrictions on corporate advertising by administrative agencies. The SEC, for example, has strictly limited the advertising of securities. See Rule 134, 17 C.F.R. § 230.134 (1972); SEC Rule 433, id. § 230.433 (1972); SEC Rule 434A, id. § 230.434a (1972) ("waiting period" provisions limiting written offerings to narrowly-drawn "tounbstone" advertisements and statutory prospectuses).

13. The impact of previous FTC orders was often limited by reliance on cease-and-desist procedure and voluntary compliance. Although the Commission has authority to promulgate industry guides, issue advisory opinions, and accept informal assurances of voluntary compliance, the FTC's power to issue trade regulation rules enforceable by the courts was denied in National Petroleum Refiner's 
ing ad hoc remedies such as corrective advertising and counteradvertising orders, ${ }^{14}$ the FTC in effect has begun to function as an equity court. ${ }^{15}$ At the same time the Cominission has even gone so far as to award damages to consumers. ${ }^{16}$

Ass'n v. FTC, 340 F. Supp. 1343 (D.D.C. 1972). See Federal Administrative

Law Developments-1972, 1973 DUKE L.J. 336.

Such informal enforcement techniques have not been sufficient. "[W]ith such an obvious disinclination .... to proceed formally we fear the business community may cease to take seriously the guides, rules, and other administrative pronouncements ... and also may cease to take seriously the statutes the FTC is empowered to enforce." ABA REPORT 26.

Aside from voluntary compliance, the cease-and-desist order has been the FTC's main weapon. Upon ascertaining a violation of a final order, the FTC may seek civil penalties of up to $\$ 5,000$ per day per violation. 15 U.S.C. 845 (l) (1970). This remedy, however, is seldom pursued. ABA REPORT 24; NADER REPORT 50. In the highly publicized "Geritol" litigation, which spanned fifteen years of investigations, evasions, compliances, and orders, the FTC sought and recently obtained fines in excess of $\$ 800,000$ - the largest such judgment ever. The makers of "Geritol" had continually flouted the FTC's final order forcing them to stop advertising the product as a cure for fatigue. See United States v. J.B. Williams Co., 354 F. Supp. 521 (S.D.N.Y. 1973). The cease-and-desist order is a potentially valuable tool. NADER REPORT 61. However, it is fraught with inherent limitations. Even when a complaint is issued, investigations, hearings, and appeals cause tremendous delay, usually until the advertising campaign is completed. Furthermore, ineffective monitoring has often failed to turn up even the most obvious violations of final orders. See ABA REPORT 28-32, 51; NADER REPORT 43, 61, 62; Connor, FTC Procedure Revisions: A Critique, 7 Vill. L. REv. 359, 362 (1962); Gellhorn, Proof of Consumer Deception Bcfore the Federal Trade Commission, 17 U. KAN. L. REv. 559, 560 (1969); Weston, Deceptive Advertising and the Federal Trade Commission: Decline of Caveat Emptor, 24 FED. B.J. 548, 561 (1964); Note, "Corrective Advertising" Orders of the Federal Trade Commission, 85 HARv. L. REv. 477, $482-83$ (1971). See generally Auerbach, The Federal Trade Commission: Internal Organization and Procedure, 48 MinN. L. Rev. 383 (1964).

14. See notes 110-28 infra and accompanying text. The FTC's recent willingness to experiment with new remedies enables the prior substantiation decisions to become more than an idle policy statement or voluntary guideline. ABA Panel Discussion, The FTC: Revitalized or Repackaged?, reprinted in part in 577 BNA ANTtTrust \& Trade Reg. Rep. A-7 (1972). The FTC has always had wide discretion in fashioning remedies, as the courts have deferred to agency expertise once the violation has been established. E.g., Moog Indus. v. FTC, 355 U.S. 411 (1958); Carter Prods., Inc. v. FTC, 268 F.2d 461 (9th Cir.), cert. denied, 361 U.S. 884 (1959).

15. See FTC v. Sperry \& Hutchinson Co., 405 U.S. 233, 244 (1972), where the Court held that the FTC "does not arrogate excessive power to itself if . . . it, like a court of equity, considers public values beyond simply those enshrimed in the letter or encompassed in the spirit of the antitrust laws." See also Charles Pfizer \& Co. v. FTC, 401 F.2d 574 (6th Cir. 1968), cert. denied, 394 U.S. 920 (1969); Luria Bros. v. FTC, 389 F.2d 847 (3d Cir.), cert. denied, 393 U.S. 829 (1968); Shell Oil Co. v. FTC, 360 F.2d 470, 479 (5th Cir. 1966), cert. denied, 385 U.S. 1002 (1967).

16. In a Coca-Cola contest case, the complaint sought to require the respondent to pay $\$ 100$ to each contestant who complied with what the FTC thought 
This Note will examine the FTC's changing consumer protection role with respect to advertising. First, the expanding definition of section 5 "unfairness" will be explored; second, the background and rationale of the Pfizer decision will be exannined; finally, the probable future implications of Pfizer for advertising will be considered.

\section{Consumerism and the FTC's Changing Role in Advertising}

\section{The Congressional Mandate-Curbing Unfair Practices}

The FTC was created with the broad goal of preventing all "unfair methods of competition in commerce."17 The draftsmen deliberately refrained from defining "unfair methods," believing that

[i]t is impossible to frame definitions which embrace all unfair practices. There is no limit to human inventiveness in this field. Even if all known unfair practices were specifically defined and prohibited, it would be at once necessary to begin over again. If Congress were to adopt the method of definition, it would undertake an endless task. ${ }^{18}$

Despite the breadth of the origimal goal, the courts adopted President Wilson's view of the Commission as a flexible imstrumentality "for doing justice to business" 19 wherever the antitrust laws and the natural market forces were ineffective in removing restraints on competition. Hence, injury to competitors was construed to be a prerequisite to FTC intervention. ${ }^{20}$

was a reasonable interpretation of the contest rules. Coca-Cola Co., 3 TRADE REg. REP. If 19,290, at 21,457 (FTC 1970). The FTC has also held it can grant restitution to consumers. Curtis Publishing Co., 3 TRase REg. REP. $\Uparrow$ 19,719, at 21,757 (FTC 1971) (although the Commission asserted its power to do so, the facts of the particular case did not warrant requiring the publishers of the defunct Saturday Evening Post to refund unfilled subscriptions); Windsor Distrib. Co. [1967-1970 Transfer Binder] TrADE REg. REP. II 18,999, at 21,260 (FTC 1969) (initial order), [1967-I970 Transfer Binder] Trade REg. ReP. II 19,157, at 21,361 (FTC 1970) (final order), enforced, 437 F.2d 443 (3d Cir. 1971) (requiring the distributor of vending machines to repurchase the machines from dissatisfied customers).

17. 15 U.S.C. $\$ 45(a)(1)$ (1914), as amended, 15 U.S.C. $\$ 45(a)(1)$ (1970).

18. H.R. REP. No. 1142, 63d Cong., 2d Sess. 19 (1914), quoted in FTC v. Sperry \& Hutchinson Co., 405 U.S. 233, 240 (1972).

19. 51 CoNG. Rec. 1963 (1914) (emphasis added). The courts supported this view early in the Commission's history. See FTC v. Sinclair Ref. Co., 261 U.S. 463, 475-76 (1923); FTC v. Curtis, 260 U.S. 568 (1923); FTC v. Gantz, 253 U.S. 421 (1920).

20. FTC v. Raladam Co., 283 U.S. 643 (1931). Although the representations in Raladam-that the drug was effective in "dissolving or otherwise removing excess flesh of the human body"-involved a drug which could not safely be used without medical supervision, there was no violation of section 5 since no harm to a competitor could be shown. Id. at 645. The "anti-fat remedy" contained desic- 
Congress reacted to this limited consumer protection role with the 1938 Wheeler-Lea Amendment to the Federal Trade Commission Act, ${ }^{21}$ which declared "all unfair or deceptive acts or practices in commerce"22 to be unlawful. The amendment's sponsors left no doubt that its primary object was to extend the same protection to consumers that the Act had given to businessmen. ${ }^{23}$ At the same time, the amendment did not attempt to proscribe particular activities, again leaving "unfairness" in each case to be defined by the FTC. ${ }^{24}$ Thus, the FTC was empowered to condemn any activity in interstate commerce "contrary to public policy."25

cated thyroid, Raladam Co., 12 F.T.C. 363,364 (1929), an ingredient made from animal glands which was "liable at all times to produce radical changes of conditions that will be harmful," id. at 368 , and "likely to create in the user . . the "laxative habit." " Id.

This prerequisite, though cumbersome, did not eliminate the consumer protection role, since injury to consumers also usually injured competitors. See, e.g., FTC v. R.F. Keppel \& Bros., 291 U.S. 304 (1934); FTC v. Algoma Lumber Co., 291 U.S. 67 (1934); FTC v. Royal Milling Co., 288 U.S. 212 (1933); 80 Cong. REc. 6436-37 (1936) (remarks of Senator Wheeler). Even if a competitor could not show his customers had been unfairly lured away by the questioned practice, a competitive injury was still relatively easy to find. "[A]ny member of industry who violated the law, any law, to promote his business [is] acting unfairly toward his competitors." Hearings on S. 3744 Before the House Comm. on Interstate and Foreign Commerce, 74th Cong., 2d Sess. 5 (1936) (statement of FTC Commissioner Davis), reprinted in WheELER-Lea ACT-A Statement of Its LegisLative RECorD 406, 412 (Dunn ed. 1938).

21. 15 U.S.C. $\S \S 41-51$ (1970), amending 15 U.S.C. $\$ \S 41-51$ (1914).

22. 15 U.S.C. $\$ 45(a)(1)(1970)$. See note 2 supra. The "in commerce" restriction on FTC jurisdiction was changed by the Senate to "affecting commerce," in the proposed Magnuson-Moss Consumer Products Warranties and FTC Improvements Act. S. 986, 92d Cong., 1st Sess., tit. II, $\$ 201$ (1971), reprinted in 117 Cong. Rec. 17,889 (daily ed. Nov. 8, 1971). Although the bill died in the House Commerce Committee, Senate action is again expected in 1973. 597 BNA ANTITRUST \& TRADE REg. REP. A-5 (1973).

23. E.g., 83 CoNG. REC. $546-47$ (1938) (remarks of Congressman Lea); H.R. ReP. No. 1613, 75th Cong., 1st Sess. 3 (1937); S. ReP. No. 1705, 74th Cong., 2d Sess. 2-3 (1936). The fact that one competitor might suffer slight economic loss was relatively unimportant. "After all, Congress is not interested in whether John Smith lost some money as the result of the advertising complained of, but the question is whether or not the general public has been deceived or injured by . . . it." 80 CONG. REC. 6593 (1936) (remarks of Senator Wheeler).

24. S. REP. No. 1705, supra note 23, at 1-2 (1936); Hearings on S. 3744, supra note 20, at 5,13 (statements by Commissioner Davis), reprinted in Dunn, supra note 20 , at 408.

25. Kritzik v. FTC, 125 F.2d 351, 352 (7th Cir. 1942), where the court held the use of punch-board games as a sales technique to be against public policy and thus violative of section 5 .

Some legislators were apparently worried that the unfairness standard inight be unconstitutionally vague and that well-intentioned individuals might not know what to do to comply. See 80 Cong. Rec. 6596 (1936) (remarks of Senator White). This fear might have been one reason the sponsors of the amendment 


\section{Judicial Search for a Standard}

The Supreme Court has avoided the question of a precise definition of "unfairness,"26 apparently relying on the belief that the FTC or the appellate courts will know unfairness when they see it. ${ }^{27}$ Thus, tying arrangements ${ }^{28}$ and the sale of nerchandise through lotteries and punch-board games ${ }^{29}$ were held to be unfair trade practices. Pre-ticketing, a manufacturer's practice of stamping standard price-tags on his product, could be held to violate section 5 where retailers habitually marked down the price, thereby misleading the consumer to beheve he was receiving a bargain. ${ }^{30}$ Nor could re-

were careful to call it a mere clarification of the 1914 Act, which was upheld in Sears Roebuck \& Co. v. FTC, 258 F. 307 (7th Cir. 1919). See S. REP. No. 1705, supra note 23, at 2-3 (1936).

Compare Interview with Robert Pitofsky, FTC Bureau of Consumer Protection Director, reprinted in 545 BNA ANTITRUST \& TrAde Reg. Rep. A-6 (1972): "Section 5 is the most marvelously flexible instrument of consumer protection that I could imagine. I have often said that if it were any vaguer it would probably be unconstitutional .... We have the capacity in this agency to review virtually every consumer problem that's going to come up."

26. The formal demand for prior substantiation, a new and far-reaching assertion of the FTC's power in economic consumer protectiomism, may lead to demands for a more definite unfairness standard. Until Pfizer and FTC v. Sperry \& Hutchinson Co., 405 U.S. 233 (1972), the need to defme "unfair" in advertising cases was lessened by the fact that most cases also charged deception, a narrower, more easily defined legal concept. In Pfizer, however, although the "entertainment" (as opposed to "information") advertisements did not deceive consumers as to any scientific testing, the FTC nevertheless stated that a claim without a prior reasonable basis was unfair. As to the FTC's antitrust jurisdiction, unfair competition was thought, until $S \& H$, to be connected with the letter or spirit of the antitrust laws. "Unfairness" in its application was thus not quite as open-ended as the history of the Wheeler-Lea Amendment and subsequent cases might indicate.

27. See note 24 supra and accompanying text. Compare Justice Stewart's concurring opinion in Jacobellis v. Ohio, 378 U.S. 184, 197 (1964), where be defined "obscenity" as "hard-core pornography." The Justice added: "I shall not today attempt further to define the kinds of material I understand to be embraced within that shorthand description; and perhaps I could never succeed in intelligibly doing so. But I know it when I see it . . . ." Id.

28. Sliell Oil Co. v. FTC, 360 F.2d 470, 479 (5th Cir. 1966), cert. denied, 385 U.S. 1002 (1967). A tying arrangement is an agreement whereby a seller will sell the desired product-e.g., gasoline-only if the buyer or gas station will in addition buy other less desirable items.

29. Gellman v. FTC, 290 F.2d 666 (8th Cir. 1961); Peerless Prods., Inc. v. FTC, 284 F.2d 825 (7th Cir. 1960), cert. denied, 365 U.S. 844 (1961); Chas. A. Brewer \& Sons v. FTC, 158 F.2d 74 (6th Cir. 1946); Kritzik v. FTC, 125 F.2d 351 (7th Cir. 1942); National Candy Co. v. FTC, 104 F.2d 999 (7th Cir.), cert. denied, 308 U.S. 610 (1939). A lottery may also be held a violation of section 5 if contrary to any local law. See note 20 supra.

30. See Rayex Corp. v. FTC, 317 F.2d 290, 292 (2d Cir. 1963). The court of appeals refused to enforce the FTC's cease-and-desist order on the ground of insufficient evidence. Id. at 295. 
tailers fail to disclose to credit customers that their negotiable notes could be assigned to a third party to whom the buyer would then be indebted and against whom the buyer's claims or defenses might not be available. ${ }^{31}$ Furthermore, the practice of routinely assigning such instruments was held inherently unfair. ${ }^{32}$ Despite the background of the Wheeler-Lea Amendment, however, cases continued to turn almost entirely on questions of unfair competition or consumer deception ${ }^{33}$ with little consideration of practices which, although not deceptive, nevertheless might be unfair to consumers.

In FTC v. Sperry \& Hutchinson Co. $(S \& H),{ }^{34}$ the Supreme Court finally recognized the legislative grant of power to develop a consumer protection standard of unfairness. The Court not only rejected the Fifth Circuit's imposition of "judicial guidelines" 35 for determining fairness, but confirmed the FTC's broad discretion to measure practices against the "elusive, but congressionally-mandated standard." 38 In this case, $S \& H$, the world's largest trading stamp company, had attempted to eliminate commercial stamp exchanges where consumers could acquire, sell, or trade green stamps without a store purchase. $\mathrm{S} \& \mathrm{H}$ also attempted to prohibit retailers from recycling green stamps by means of unauthorized merchandise redemptions. These actions not only would have imcreased the retailers' demand for green stamps, but would have either obligated consumers to continue shopping at those chain stores that dispensed the stamps or limited the utility of consumers' unredeemed stamps. ${ }^{37}$ Although the FTC and the trial exammer confimed their decisions

31. All-State Indus., Inc. v. FTC, [1967-1970 Transfer Binder] TrADE REo. REP. $\pi$ 18,740, at 21,105 (FTC 1969), enforced, 423 F.2d 423 (4th Cir.), cert. denied, 400 U.S. 828 (1970).

32. Id.

33. See, e.g., Heinz W. Kirchner, 63 F.T.C. 1282 (1963); see notes 57-60 infra and accompanying text. See also Pfizer, Inc., 3 TrADE REo. ReP. II 20,056, at 22,032 (FTC July 11, 1972); General Motors Corp., 53 F.T.C. 1239 (1957) (dismissing a complaint against the "your Chevrolet knows the difference" advertising campaign, which was held not deceptive even though it alleged that identical replacement parts made by manufacturers other than Chevrolet might perform less dependably than Chevrolet parts).

34. 405 U.S. 233 (1972), modifying 432 F.2d 146 (5th Cir. 1970).

35. The Court of Appeals for the Fifth Circuit had said:

To be the type of practice that the Commission has the power to declare "unfair" the act complained of must fall within one of the following types of violations: (1) a per se violation of antitrust policy; (2) a violation of the letter of either the Sherman, Clayton, or Robinson-Patman Acts; or (3) a violation of the spirit of these Acts as recognized by the Supreme Court . . . 432 F.2d at 150 .

36. 405 U.S. at 244.

37. Id. at 236-37. See generally Note, Trading Stamps, 37 N.Y.U.L. REv. 1090 (1962). 
to the issue of unfair competiton, ${ }^{38}$ the Supreme Court indicated that economic injury to the consumer independently could result in a section 5 violation. ${ }^{38}$ Thus, the Court ensured that the FTC's broad discretionary powers would be equally available to its consumer protection efforts. ${ }^{40}$

The $S \& H$ decision confirmed the Coinmission's own view of "unfairness" as a dynamic, analytical concept with which the FTC could create "a new body of law" adaptable to changing needs and conditions. After $S \& H$, according to one FTC official, practices do not have to cause injury to be held unfair, but need only be immoral, unethical, or oppressive. ${ }^{42}$ The General Counsel of the Com-

38. Sperry \& Hutchinson Co., [1965-1967 Transfer Binder] TRADE REg. ReP. II 17,862, at 23,219 (FTC 1967) (trial examiner), [1967-1970 Transfer Binder] TRAde REg. ReP. If 18,449, at 20,792 (FTC 1968) (Commission final order).

39. 405 U.S. at 239 . The importance of this decision is two-fold. Not only did the Court confirm the FTC's role in consumer protection cases, but by holding that the Commission could proscribe practices as unfair even though there was no violation of the letter or spirit of the antitrust laws, the Court also expanded the FTC's antitrust jurisdiction. Id.

40. It is difficult to imagine a looser set of jurisdictional restrictions than $S$ \& $H$ 's. In addition to challenging unfair advertising practices, the FTC has formulated plans under the $S \& H$ mandate to ban the holder-in due-conrse doctrine, see text accompanying note 32 supra, and to investigate the credit market, debtor's rights, and garnishment practices. Pitofsky Interview AA-3. Such loose standards of unfairness may even carry FTC regulation beyond antitrust or consumer protection orders. Recently a petition was filed with the FTC against two paper mills, alleging that excessive pollution was an unfair trade practice and an unrevealed material fact affecting consumer purchases. See 563 BNA ANTrTRUST \& TRADE REg. REP. A-20 (1972). At the very least, "excessive" pollution, implying the avoidance of required abatement costs, creates a competitive advantage and arguably is subject to the FTC's public policy balancing test."

In addition to the novel economic issue, this petition poses the serious question whether the FTC can legitimately decide issues that affect not only sellers and potential buyers of consuiner goods, but all facets of society. Since administrative agencies are created to infuse an often highly technical expertise into governmental decision-making, they would seem ill-equipped to make decisions with such potentially wide ranifications outside their narrow area of regulation. See ColgatePalmolive-Peet Co. v. NLRB, 338 U.S. 355 (1949); Hastings Mfg. Co. v. FTC, 153 F.2d 253 (6th Cir.), cert. denied, 328 U.S. 853 (1946); 1 K. Davis, AdmanisTRATIVE LAW TREATISE $\$ \$ 1.05,2.05$ (1958).

41. All-State Indus., [1967-1970 Transfer Binder] Trade Reg. Rep. If 18,740, at 21,105 (FTC 1969). See also FTC v. Standard Educ. Soc'y, 86 F.2d 692, 696 (2d Cir. 1936), rev'd on other grounds, 302 U.S. 112 (1937).

42. Address by Gerald Thain, Assistant Director for National Advertising, FTC Bureau of Consumer Protection, reprinted in part in 558 BNA ANTTIRUST \& TrAde Reg. ReP. A-14 (1972). In quoting from the Statement of Basis and Purpose of Trade Regulation Rule 408, 16 C.F.R. \& 408 (1972), which covers the unfair advertising and labeling of cigarettes, $S \& H$ and Pfizer stated that the question of an act's unfairness was to be determined by these factors: "( 1 ) [whether the act is] within ... the penumbra of some common law, statutory, or 
mission has envisioned an equally open-ended test where the FTC would balance the business reasons for a questioned act against any public values it deems relevant. ${ }^{43}$

\section{The Pfizer CASE}

The FTC's view of its own power was formally expressed in Pfizer, Inc.4 In Pfizer, the FTC challenged television advertisements portraying a tanned, bikini-clad model applying a sun-burn product while cooing that "Un-Burn anesthetizes nerves" and "reheves pain fast." 45 Similar radio claims were also challenged. The staff complaint, besides charging deception, alleged that Pfizer committed unfair acts by advertising "Un-Burn's" pain-relieving qualities without well-controlled scientific studies or tests to substantiate the claims. ${ }^{46}$ Although the FTC held that well-controlled scientific tests were not necessary to avoid liability under section $5,{ }^{47}$ the Commission cautioned that a positive claim without a prior reasonable basis would be unfair to the consumer because such a claim would impair his ability to make a rational product choice and would force him to bear the economic risk that the product might not perform as advertised. ${ }^{48}$ Making an unsubstantiated clain would also be unfair to competitors, who, although able to compete on the basis of price, service, or quality, might otherwise lose prospective customers enticed by the representations. The rationale of Pfizer was clear: the economic risk that a product might not yield the expected result should be borne by the manufacturer through the prior substantiation of advertising claims, rather than by the consuiner who

other estabhshed concept of unfaimess; (2) whether it is immoral, unethical, oppressive, or unscrupulous; (3) whether it causes substantial injury to consumers or competitors or other businessmen." FTC v. Sperry \& Hutchinson Co., 405 U.S. 233, 244-45 n.5 (1972); Pfizer, Inc., 3 TrADE REg. REP. II 20,056, at 22,032 (FTC July 11, 1972).

43. Statement of Richard Dietrich, FTC General Counsel (Panel Discussion, ABA Antitrust Law Section), reprinted in part in 577 BNA ANTITRUST \& TRADE REg. REP. A-9 (1972); cf. Alberty v. FTC, 182 F.2d 36, $38-39$ (D.C. Cir. 1950). This parallels the earlier extreme view of a Commission with the power to proceed against any conduct it feels is contrary to public policy. See note 25 supra and accompanying text.

44. 3 TrADE Reg. ReP. If 20,056, at 22,029 (FTC July 11, 1972).

45. The following claims were challenged: (1) "New Un-Bum actually anesthetizes nerves in sensitive sunburn skin"; (2) Un-Burn "contains the same local anesthetic doctors often use"; and (3) "Un-Bum relieves pain fast." Pfizer, Inc., [1967-1970 Transfer Binder] TRADE REg. ReP. II 19,209, at 21,388 (FTC 1970) (proposed complaint).

46. Id.

47. Pfizer, Inc., 3 Trade Reg. Rep II 20,056, at 22,036 (FTC July 11, 1972).

48. Id. at 22,029 . 
relies upon those claims and who would suffer economic loss should the claims prove false. ${ }^{49}$

\section{The Reasonable Basis Test}

In establishing the "reasonable basis" test, the FTC explained in Pfizer that the standards against which the advertiser's actions must be measured are to be formulated in each case. Thus the type and amount of data required to provide a reasonable basis for a clain would vary with the type and specificity of the advertisement, the nature of the product, the possible consequences of a false claim, the type and accessibility of evidence, and the likely reliance on the claim by consumers. ${ }^{50} \mathrm{~A}$ safety claim involving a potentially dangerous product would be held to a higher standard of reasonableness than, for example, an efficacy or performance claim that at most would result in a small economic loss. For some potentially hazardous products, the only reasonable basis would be scientific or medical tests. ${ }^{51}$ In other cases, studies of scientific, medical, or trade literature, an analysis based on general medical knowledge, or even the experienced and informed judgment of experts might be sufficient. ${ }^{52}$

Despite the FTC's attempt to clarify its standards, an advertiser's obligations under the reasonable basis test are unclear. To decide whether his proposed advertisement has a reasonable basis, the advertiser apparently must first examine the claims in terms of the variable factors armounced in Pfizer. He should then weigh the substantiating data against specific values he lias assigned to each factor and against the relative importance of eacli factor generally, though the FTC could go through the same procedure and still reach

\section{See id.}

50. Id. at 22,034 .

51. See id.

52. Lest the FTC become embroiled in a battle of testing experts, however, the Commission was quick to point out that its limited role would be "to determine the existence and general quality of the tests and a threshold determination as to the reasonableness of reliance thereon, rather than an attempt to conclusively determine the adequacy of the tests." Pfizer, Inc., 3 TRADE REg. REP. $\prod$ 20,056, at 22,035 n.22 (FTC July 11, 1972).

Since the FTC's concern is with the method of marketing, the ultimate performance of the product as advertised is not enough to avoid section 5 prosecution. See note 48 supra and accompanying text. Although tests conducted and experts consulted after the representation is first made are irrelevant to the prior substantiation complaint, the Commission nonetheless determined that even subsequent testing failed to prove "Un-Burn's" anesthetizing claims. These tests compared "Un-Burn" with a neutral substance rather than with the level of effectiveness represented in its commercials. Id. at 22,035 n.23. 
the opposite result. ${ }^{53}$

In addition to being difficult to apply, the Pfizer test may exceed the Commission's legislative mandate. Despite anticipation that some acts would be unfair and not deceptive, ${ }^{54}$ it is apparent that Congress did not expect that the legality of an advertisement would turn on factors other than truth or falsity, as was the case in Pfizer. Senator Wheeler, one of the authors of the 1938 Amendment, when asked what the FTC could do under the proposed legislation about the hypothetical claim, "my rayon is the best in the world, superior to any other," replied:

If [the manufacturer] said in his advertisement that it was the best in the world, and he was honestly of the opmion that it was the best in the world, the Federal Trade Commission could ordinarily not do anything about it .... The object of the proposed legislation is not to stop the issuing of exaggerated opinions with reference to one's own articles. ${ }^{55}$

53. The Pfizer facts may be used to illustrate the application of the new FTC standard. Although safety tests were made on both animals and lrumans, no efficacy or performance tests on lumans were conducted prior to the advertising campaign stressing "Un-Burn's" anesthetic effects. Further, the efficacy tests employed were not persuasive; injections of benzocaine into guinea pigs could lardly substantiate claims that surface applications anestletized liuman nerves. On the contrary, there is evidence which indicates that benzocaiue as a treatment for pain from burns is no more effective than cold water or the neutral jelly in which "Un-Burn's" "active" imgredient was marketed. Consumers UNION, ThE MEDICINE SHow 136-37 (1963).

Pfizer's use of clinical data to slow that benzocaine and menthol had been used by doctors for at least fifty years in treating sunburn pain, 3 TRADE Rro. REP. II 19,614, at 21,656 (FTC 1971) (trial examiner's decision to dismiss charges), is equally vulnerable under the reasonable basis test. Pfizer's historical searcli may liave been so limited as to be unreasonable, or the literature may lave been too ambiguous or contradictory to support the claim. Conclusions drawn from the reviewed material may liave been unreasonable if only the ingredients were analyzed and not the final product combination. Further grounds for complaint would exist if all the potential uses of the product were not investigated. With "Un-Burn," for example, the effect of the product on various skin types and on burns of different degrees should have been thoroughly examined. 3 TRADE REg. Rep. TI 20,056, at 22,037 n.30 (FTC July 11, 1972). Finally, the qualifications and potential biases of investigators could be questioned to impeach the reasonableness of the advertiser's effort, since the FTC demands at a minimum that significant resources and trained personnel be devoted to the research and testing functions.

54. See Hearings on H.R. 3143 Before the House Comm. on Interstate and Foreign Commerce, 75th Cong., 1st Sess. 5 (1937), reprinted in Dunn, supra note 20 , at 467 (statement of Commissioner Davis that coinpanies may engage in many unfair practices, such as bribery, which are not deceptive).

55. 80 Cong. REC. 6592 (1936) (emphasis added). Senator Wheeler's reasoning would seem automatically to preclude an attack on that part of the "UnBurn" advertisement that claimed the product went to work "fast." Similarly, 
Senator Wheeler went on to state that after the amendment, the FTC could investigate if the advertisement was a statement of fact which could be demonstrated as true or false; but if a statement was made where there could be differences of opinion, the FTC should not proceed. ${ }^{56}$ Although the Commission was to have wide latitude in defining and preventing unfair acts, these acts were ultimately to be judged against the truth insofar as it was ascertainable.

Although apparently not contemplated by Congress, the Pfizer reasonable basis test was foreshadowed by several FTC and lower

words such as "easy," "perfect," "amazing," "prime," "wonderful," and "excellent" have in the past been regarded as lawful trade puffing. Carlay Co. v. FTC, 153 F.2d 493, 496 (7th Cir. 1946). See note 12 supra.

During the Senate debate on the 1938 Amendment, Senator Wheeler stated:

[I]f the manufacturer said, "My car is the best car on the market for the money," there would be a vast difference of opinion in the general public's mind as to whether it was or not .... It would be a very difficult thing to prove that the car was not just what the manufacturer said it was. Those are things which are generally recognized by the courts as not capable of being reached by any law. 80 CoNG. REC. 6592 (1936).

Senator Norris added:

[That] such a statement would clearly bring the automobile manufacturer under ... the bill ... technically ... may be right. As a practical proposition, however, it is of no consequence, because any man of experience knows that he never could obtain the enforcement of a ceaseand-desist order ..... Id. at 6592-93 (1936).

Congress thus did not directly consider the implications of the Act on trade puffing, since in practical terms, the contradictory testimony would foreclose the Commission from satisfying the burden of proving falsity or deception. The draftsmen of the amendment clearly did not anticipate a reasonable basis doctrine that would shift the burden of coming forward with evidence and would declare a section 5 violation based on the very existence of contradictory evidence. But the new doctrine could be construed to prohibit this previously exempt trade "puffing."

The FTC may already have acted in this direction. There is very hittle difference between the hypothetical rayon claim, thought beyond FTC regulation, and the claims of superior headache relief and automobile handling capability currently under attack. See notes 72-75 infra and accompanying text. The Guidelines on Advertising Substantiation, published to ease compliance with new FTC orders, also seem to conflict with Congressional understanding of the FTCA. To distinguish Senator Wheeler's lawful "exaggerated opinions" from presently proscribed unfair representations necessitates drawing a very thin line. The prohibition. contained in the Guidelines seems to fall somewhere between the two categories. See, e.g., Guideline Number 9: "Advertisers should avoid exaggerated statements and demonstrations which reasonably could be misconstrued by consumers, 'dangling' comparatives, and any intentional distortion of fact, as well as unsubstantiated claims of uniqueness." Guidelines on Advertising Substantiation, reprinted in 588 BNA ANTITrust \& Trade REg. Rep. A-10 (1972). An example of a "dangling comparative" might be the claim by Phillips tablets_-"they're smaller, but they're stronger." Advertisers apparently can no longer announce that their products are qualitatively "superior," comparatively "better," or even different from competing products without a sufficient prior basis. See notes 79-82 infra and accompanying text.

56. 80 CoNG. Rec. 6592 (1936). 
court decisions. In H.W. Kirchner, ${ }^{57}$ an advertisement claimed that an "invisible" inflatable swimming aid would make the wearer "unsinkable" when it was slipped inside a bathing suit. The FTC overruled the trial examiner by holding that the "invisibility" claim was a hyperbole "too far-fetched" to warrant intervention, but the Commission then upheld the examiner's finding that the "unsinkable" claim was deceptive. ${ }^{58}$ In essence, the FTC treated separately those claims involving potential health and safety hazards:

While we are not deciding the instant case on such a ground, we are inclined to think that an advertiser is under a duty, before he inakes any representation which, if false, could cause injury to the health or personal safety of the user . . ., to make reasonable inquiry into the truth or falsity of the representation. ${ }^{59}$

Unlike Pfizer, the Commission in Kirchner did not advocate a reasonable basis test based on a detailed evaluation of the marketing method and risk factors. Rather, under Kirchner, substantiation would be sufficient only if it satisfied a reasonably prudent businessman, acting in good faith, that the claim was true. ${ }^{00}$

In Tashof v. FTC, ${ }^{61}$ the Court of Appeals for the District of Columbia Circuit enforced an FTC order which proscribed practices that might result in economic injury similar to that discussed in Pfizer. The New York Jewelry Company had claimed to be a discount seller of eyeglasses-a claim the FTC held was false, after discovering that the company, through various "bait and switch" techniques, had sold fewer than 10 pairs out of a total of 1,400 for the advertised price of $\$ 7.50 .^{62}$ The cease-and-desist order prohib-

57. 63 F.T.C. 1282 (1963).

58. Id. at 1290; see notes 138-39 infra and accompanying text.

59. 63 F.T.C. at 1294. Compare Pfizer, Inc., 3 TRADE REg. REP. If 20,056, at 22,034 (FTC July 11,1972 ).

60. By recommending a reasonably prudent businessman standard, the FTC apparently made the assumption that a greater or lesser amount of proof would satisfy a busimessman than would satisfy an average reasonable man. The rapid expansion of products liability might indicate that a businessinan would be more wary of product claims than the average consumer. See Hansen v. Firestone Tire \& Rubber Co., 276 F.2d 254 (6th Cir. 1960); Greenman v. Yuba Power Prods., Inc., 59 Cal. 2d 57, 377 P.2d 897, 27 Cal. Rptr. 697 (1963); Rogers v. Toni Home Permanent Co., 167 Ohio St. 244, 147 N.E.2d 612 (1958); Note, Products Liability and Evidence of Subsequent Repairs, 1972 Duke L.J. 837. If, on the other hand, the standard assumes a reasonable businessman will be persuaded by less evidence, thus making it easier to satisfy the Commission's test, the Kirchner standard would be less rigorous than the Pfizer test.

61. 437 F.2d 707 (D.C. Cir. 1970).

62. Leon A. Tashof, [1967-1970 Transfer Binder] Trade REg. REP. II 18,606, at 20,941 (FTC 1968), enforced, 437 F.2d. 707 (D.C. Cir. 1970).

The "bait and switch" technique is one whereby a seller advertises a product 
ited the company from advertising "discount prices" in the future without first conducting a "statistically significant survey" in its trade area to show that the prevailing price was "substantially" higher than New York Jewelry's. ${ }^{63}$ Unlike Kirchner, the Tashof representations only involved the price of the product and the risk of economic injury. There were no allegations that any of the eyeglasses did not meet advertised quality standards. The consumers' reliance ${ }^{64}$ and possibly the nature of the product as one necessary to those with poor eyesight were the only Pfizer variables present which militated for a high degree of prior substantiation. ${ }^{65}$ Furthermore, a Kirchner health or safety problem would not be involved except insofar as the advertisement induced customers with poor eyesight to take a potentially hazardous downtown trip.

\section{BEYOND Pfizer}

The FTC has indicated that Pfizer's reasonable basis requirement is not the limit of its intended consumer protection effort. ${ }^{86}$ In Firestone Tire \& Rubber Co. ${ }^{67}$ the FTC required substantiation by scientific tests of claims that the "Wide Oval" tire was "safe,"68

at an unusually low price to attract the customer. Then the potential buyer is either persuaded to make "the better buy" when the salesman points out all the deficiencies in the advertised special, or he is forced to buy a second product to take advantage of the bargain. See also Great Atlantic \& Pacific Tea Co., 3 TrADE REg. ReP. If 20,060, at 22,041 (FTC July 27, 1972), in which the FTC is seeking to force $A$ \& $P$ Food Stores to cease and desist from advertising specials with very limited quantities of the advertised products on hand in each store.

63. 437 F.2d at 713. A survey may be the only acceptable substantiation for "discount" advertisements. Id.; General Motors Corp., 3 TRADE REg. REP. II 20,120, at 22,103 (FTC Oct. 12, 1972) (proposed order would require advertised economy characteristics to be backed by "qualitative data based on a statistically valid sample, or other appropriate substantiating material").

However, Judge Robb, dissenting in Tashof, argued: "[T]he Commission exceeds its authority when it requires [the New York Jewelry Company] to conduct a 'statistically significant survey' .... . This requirement shifts to NYJC the burden of proving its innocence; and ... might subject NYJC to heavy civil penalties even if its advertisement is true." 437 F.2d at 715 (dissenting opinion). See notes 144-45 infra and accompanying text.

64. On the other hand, it is arguable that the initial reliance on low prices only brought consumers to the store to be subjected to bait-and-switch salesmanship and thus did not directly induce any purchases.

65. See note 50 supra and accompanying text.

66. It should be noted, however, that the dismissal prevented any immediate testing of the doctrine in court, a circumstance which caused one Commissioner to dissent from the disposition of the case. Pfizer, Inc., 3 Trade REg. REP. II 20,056, at 22,039 (FTC July 11,1972 ).

67. 3 TRADE REG. ReP. II 20,112, at 22,077 (FTC Sept. 22, 1972). For a history of Firestone's "safe-tire" controversy, see Bishop 132-35.

68. 3 TrAde REg. Rep. If 20,112, at 22,081 (FTC Sept. 22, 1972). It should be noted that there were two dissents from this position. Id. at 22,088-94. 
even though a general scientific testing requirement had been rejected in Pfizer. ${ }^{69}$ Also, the FTC recently has challenged representations which do not involve specific safety claims and which, under Pfizer, would not require a high degree of substantiation. ${ }^{70}$ The Commission has issued proposed complaints challenging ambiguous advertising claims ${ }^{71}$ by automobile manufacturers. ${ }^{72}$ In

The Consumer Product Safety Act, Pub. L. No. 92-573 (Oct. 27, 1972), reprinted in U.S. CODE CONG. \& AD. News 6021-53 (1972), created an independent Consumer Product Safety Commission with power to accumulate and disseminate information concerning personal injuries caused by specific products, to pass mandatory safety standards, and to ban products creating imminent hazards to consumers. Despite the assertion that the FTC is primarily an investigative and not a regulatory body, National Petroleum Refiner's Ass'n v. FTC, 340 F. Supp. 1343 (D.D.C. 1972), regulation by the FTC of safety claims is not expected to decrease. See Hercules, Inc., 3 Trade Reo. ReP. ff 20,131, at 22,120 (FTC Nov. 1, 1972) (proposed compiaints against pesticide manufacturers).

69. In National Petroleum Refiner's Ass'n v. FTC, 340 F. Supp. 1343 (D.D.C. 1972), the FTC was denied substantive rule-making power. Thus in Firestone the FTC stated that the scope of the reasonable basis test was limited "at this time" to determinations on a case-by-case basis. 3 TRADE REG. REP. $\{20,112$, at 22,081 (FTC Sept. 22, 1972). By pointedly restricting its role to ad hoc decisionmaking, the Commission might be looking forward to the overruling of National Petroleum, either on appeal or by legislative fiat. See proposed Consumer Product Warranties and FTC Improvements Act, S. 986, 92d Cong., 1st Sess. (1971), reprinted in 117 CoNG. REC. 17,887 (daily ed. Nov. 8, 1971). The National Petroleum decision dealt a serious blow to the Commission's planned enforcement program by holding that, unlike the SEC, the FTC had no authority to issue sub. stantive regulations enforceable in court. Thus, when the Commission promulgates a rule under section $6(\mathrm{~g})$ of the FTCA, 15 U.S.C. $\S 46(\mathrm{~g})(1970)$-for example, declaring the failure to post octane numbers on gasoline pumps unfair and deceptive-the rule is open to full-scale judicial review in each case. The district court in National Petroleum even went so far as to state that the FTC was created expressly as an investigative and not as a regulatory body. $340 \mathrm{~F}$. Supp. at 1345. See generally Federal Administrative Law Developments--1972, supra note 13.

The broad language of the $S \& H$ decision may indicate that the FTC will get a sympathetic audience when the Supreme Court evaluates the Commission's rulemaking power. In $S \& H$ the Court approvingly quoted from a trade regulation rule. See note 42 supra. If and when the FTC's rule-making authority is confirmed, the Commission may be willing to codify "reasonable basis" in order to clarify the boundaries of FTC regulation.

70. Although there is some indication that health and safety claims may be treated as a separate advertising category, see text accompanying note 59 supra, the high degree of prior substantiation required in Firestone might easily be understood by a cursory evaluation of the Pfizer factors. The "safe tire" claims were specific, citing statistics instead of using an entertainment format; the product was one upon which the personal safety of the user depended; and the supporting evidence was peculiarly accessible to the manufacturer. See text accompanying note 50 supra.

71. These ambiguous representations-advertisements conveying both true and misleading claims-currently cause most of the FTC litigation. See Gellhorn, supra note 13, at 563 (1969). It might be argued that by adding misleading "secondary" meanings to a true statement, the advertiser is precluded from claiming 
these cases, the FTC's challenge, although couched in "reasonable basis" language, necessarily focuses on what is actually truth in the context of the advertiseinent. For example, a claim that a certain make of automobile "never quit" in 130,000 miles is meaningless until the auto-1naker defines "quit."

\section{Claims of Uniqueness}

Perhaps the most important substantive innovation to arise from the new reasonable basis test has been the challenge to uniqueness representations. The FTC recently issued complaints against the major manufacturers of analgesics, each of which had made various claims of superior pain relief and unique performance. ${ }^{74}$ The complaints did not charge falsity, but alleged that no reasonable basis existed for unqualified claims of therapeutic differences among products or even for assertions that the products were superior to plain aspirin. The mere inaking of these claims, at least in an informational setting, implied they had been "established," when, according to the FTC,

[t]here is a general background of ignorance in the scientific community on how analgesics work. Tests controdict [sic] one another. In light of the great mass of contradictory data, to make unqualified claims against that background is unfair. ${ }^{75}$

to be acting in good faith, and is thus subjected to liability under the good faith test suggested by Kirchner. See text accompanying note 60 supra.

72. One challenged advertisement reads in part:

There's only one way, really, to find out what a Chevy Vega is all about, and that's to drive one. Road \& Track Magazine drove one and wound up saying ... 'Vega is beyond a doubt the best handling passenger car ever built in the U.S.' Notice they didn't say the best handling little car ... or the best handling economy car, but simply the best handling passenger car .... [W] ho'd expect an economical little car like Vega to be a hero on the highway?" General Motors Corp., 3 TRADE REg. REP. Tा 20,120, at 22,103 (FTC Oct. 12, 1972) (proposed complaint).

The FTC also recently issued a proposed complaint against a Ford Motor Company advertisement that implied Ford's side-guard beams are as strong as highway guardrails. Ford Motor Co., 3 TRADE REg. REP. \ 20,218, at 22,216 (FTC Feb. 8, 1973).

73. See 593 BNA Antrtrust \& Trade Rzg. Rep. A-1, A-2 (1972) (advertisement for Toyota for which the FTC has demanded substantiation).

74. Bristol-Myers Co., 3 Trade Reg. ReP. II 20,263, at 22,292 (FTC Feb. 23, 1973) (involving the manufacturers of "Anacin," "Bufferin," "Excedrin," "Bayer," "Cope," "Vanquish," and "Midol"). The investigation behind these complaints has lasted over ten years. See FTC News Release, 3 TRADE REG. REP. II 10,117, at 18,603 (June 27, 1962). However, since less than ten percent of all initiated investigations even reach the proposed complaint stage, it would not have been atypical for the FTC to have quietly dropped the case. See Address by FTC Executive Director Menzies, reprinted in 5 TRADE REg. REP. If 50,138, at 55,228 (June 12, 1972).

75. 560 BNA ANTtrRust \& Trade Reg. Rzp. A-3 (1972) (announcement of proposed analgesics complaint by FTC Bureau of Consumer Protection Director Pitofsky). 
The theory of this complaint-that a claim for which there is conflicting evidence is necessarily unfair-makes the reasonable basis requirement look more like a requirement of conclusive proof. Even Pfizer did not go so far as to suggest that a conflict or general ignorance among the experts would prohibit a product claim based only on one school of thought. On the contrary, the Commission in Pfizer suggested that conflict in the medical literature was insufficient proof that "no reasonable basis" existed when the advertiser was attempting to draw on clinical experience. ${ }^{78}$ Should the FTC accept the theory of the analgesics complaint, any claim contradicted by a credible minority expert or validated by less than conclusive evidence could be held insufficiently substantiated. ${ }^{77}$ The problems with this approach are apparent. If one accepts the premise that a large enough group of experts would probably have difficulty agreeing on anything, ${ }^{78}$ one could envision every affirmative product claim subject to challenge on the basis of every competitor's product claim. Every headache remedy would not be perinitted to advertise greater pain relief qualities than all the rest; but one product could assert its superiority so long as the competitors conceded the claim, an unlikely occurrence. Makmg every product representation consistent with all other competing advertising claims would appear to be an impossible goal for even the most energetic, abundantly financed Commission.

In addition to these difficulties, the arguments permitting chal-

76. 3 TRADE REg. REP. If 20,056, at 22,039. Although the Supreme Court has given the FTC the power to define unfairness in each case, the Commission may finally have indicated that, even after Pfizer, the unfairness concept is not boundless. Rather the FTC could place self-imposed restrictions on its jurisdiction in the form of a rule, should the rule-making power be upheld. See note 69 supra. Thus, the National Petroleum case, if upheld, might actually force future, less activist Commissions to take jurisdiction in questionable cases or at least to exercise a case-by-case discretion, instead of allowing the FTC to fall back on a limiting trade regulation rule.

77. By issuing a complaint against General Motors for advertising that "Vega is the best handling passenger car ever built in the United States," see note 72 supra, even though the quotation was directly attributed to an independent Road \& Track magazine study, the FTC may have already indicated its acceptance of the conclusive proof theory.

78. See 560 BNA ANTITRUst \& Trade Reg. ReP. A-3 (1972) (response of Bristol-Myers' products president to the proposed complaints issued against analgesic manufacturers). Compare McKay v. State, 235 S.W.2d 173 (Tex. Crim. App. 1950), where, in ruling on the admissibility of scientific evidence-the results of a Harger Drunkometer test-in a criminal trial before a jury, the court asserted: "In all probability a scientist may be found who will disagree with practically every generally accepted scientific theory. We will take judicial knowledge of the scientific fact that the earth is round. At the same time, we know there are still individuals who claim to be scientists who have other theories . . . " Id. at 174. 
lenges of uniqueness claims based on contradictory evidence may lead to an attack on product differentiation in all advertising. The FTC has long recognized that large firms in consumer goods industries tend to manufacture similar products and create artificial distinctions through advertising to affect price and demand. Convincing the consumer that one product is somehow faster, stronger, more pleasant, or more economical than all competing products is the primary goal of advertising. ${ }^{79}$ Toothpastes, deodorants, cleansers, soaps, and detergents generally are priced from five to twenty times the cost of production; forty percent of the product price is spent on "creating" product differentiation. ${ }^{80}$ Pfizer touched on the problein of artificially differentiated products by warning that a manufacturer who utilizes only trade information gathered by competitors has no reasonable basis for advertising claims unless the prior testing involved an identical counbination of ingredients. ${ }^{81}$ Of course, the admission that identical products exist negates claims of differentiation. The advertiser could avoid this Pfizer dilemma by making tests on his own, a positive end in itself according to the reasonable basis doctrine. ${ }^{82}$ Nevertheless, in that adumbrative world beyond

79. See, e.g., Bishop 105-22; NADER REPORT 21-24; Thain, Drug Advertising and Drug Abuse-The Role of the FTC, 26 Food Drug Cosm. L.J. 487, 489 (1971); Travers 555; Comment, Psychological Advertising: A New Area of FTC Regulation, 1972 WIs. L. REv. 1097.

80. NADER RePort 21. See also Travers 555; Comment, The First Amendment and Consumer Protection: Commercial Advertising as Protected Speech, 50 ORE. L. REv. 177, 183 (1971).

One example of advertising which creates nonexistent distinctions occurs in the gasoline industry. There is so little difference among premium brands that the major oil companies even exchange gas with each other to eliminate the effect of fluctuations in demand. Shell Oil Company has an advertisement showing the Shell-fueled car, with "platformate" in the gasoline, crashing through a paper curtain set up where the car without the Shell ingredient had conne to a stop. The advertisement of course does not mention that all brands of gasoline contain the very non-unique ingredient platformate. BisHop 112-13, 172-73. See also 32 CONSUMER REP. 360 (1967) (describing the advertising success of Clorox, which, although identical to most other bleaches, has been able not only to dominate the market but also to charge ten to fifteen percent more for the product than competing brands). .

81. 3 Trade Reg. Rep. $\Uparrow 20,056$, at 22,037 n.30.

82. However, private-label manufacturers and small-time producers who advertise on a comparison basis with branded products are more vulnerable than larger corporations, since they can no longer rely merely on whatever substantiation their larger competitor has. Nor can these smaller concerns afford the large testing staffs available to the wealthier corporations. The FTC's protection of the consumer might ironically in some cases inhibit its twin function of encouraging competition. But see 517 BNA ANTITRUST \& TrADE REg. REP. A-1 (1971) (Burear of Competition Director's belief that informal advertising substantiation program will increase competition by making complaints against the larger advertisers more common and easier to justify). 
Pfizer, one must question whether any advertisement which does no more than attempt to create an artificial product distinction can withstand the FTC's rigorous "unfairness" challenge.

\section{Nonrational Appeals}

Another advertising technique to which the Pfizer decision might easily be extended is the nonrational appeal-that deliberately uninformative advertisement which causes the consumer to buy a product without regard to price or quality. The FTC could demand substantiation for such "claims" and thus force the advertiser to attempt to justify the advertisement's implications. ${ }^{83}$ For example, substantiation might be required for statements that a mouthwash or toothpaste enhances sex appeal, that a cold cream restores youthful beauty, or that possessing a certain automobile revitalizes the owner's dating prowess. ${ }^{84}$ Some observers have advocated complaimts against such nonrational advertisements, ${ }^{85}$ and one FTC official has already recognized this possibility. ${ }^{80}$ The ques-

83. The FTC has not confined the extension of Pfizer to explicit uniqueness representations; instead, the Commission appears to include implied uniqueness claims. See Ford Motor Co., 3 TrAdE REg. REP. If 20,218, at 22,216 (FTC Feb. 8, 1973) (proposed complaint against implied claims that Ford's side-guard beams were as strong as highway guardrails); ITT Continental Baking Co., 3 TrAde REg. REP. If 19,539, at 21,613 (FTC 1971) (proposed coinplaint attacked implied nutritional uniqueness claims for "Wonderbread"); speech by Gerald Thain, reprinted in part in 558 BNA ANTrTRUST \& TRADE REg. REP. A.14 (1972) (noting the trend toward prohibition of implied uniqueness claims); 570 BNA ANTITrust \& TrADE REg. REP. B-3 (1972) (recognizing the challenge in the "Wonderbread" case as the beginning of an important trend); cf. Alberty v. FTC, 182 F.2d 3.6, 38-39 (D.C. Cir. 1950).

84. See Guidelines on Advertising Substantiation, Nos. 7, 11, reprinted in 588 BNA ANTtTrust \& TRADE REg. REP. A-10 (1972). Although the sexual "aura" of the "Un-Burn" advertiseinents was probative only of the entertainment as opposed to the scientific character of the representations, at least one commentator has challenged all use of sexual appeals. See Thain, supra note 79, at 499. FTC official Thain "would question the fairness of any advertisement which exploits the aspirations of married women by representing that a product ... can and will be effective in making thein attractive and exciting to their husbands." Id.

85. See Alexander, Federal Regulation of False Advertising, 17 U. KAN. L. REv. 573, 582-84 (1969). The proscription of nonrational appeals would eliminate "pastoral scenes and nubile maidens cavorting on beaches, pleasant scenes to behold, but suggestive of no rational basis for the preference of the product." Id. at 584. See also Thain, supra note 9, at 621-22; Comment, supra note 79.

86. In response to the "still-unanswered question" whether advertising that induces nonrational consumer purchases is unfair under section 5 , Bureau of Consumer Protection Director Robert Pitofsky stated:

Again I suppose the staff could recommend a complaint like that. I believe any such case would be unwise. The definition of a nonrational experience is so elusive that I wouldn't know how to propose enforcing a 
tion of regulation in this area nay become increasingly acute if the reasonable basis requirement ironically causes advertisers, in avoiding the prior substantiation of factual claims, to abandon information advertising in favor of inood or entertainment commercials. ${ }^{87}$ Should the FTC proceed against nonrational advertisements, new problems will arise. The FTC will be forced to define "nonrational" and to formulate the reasonable basis standards, if any, for such nonrational advertisements.

In addition to "wandering into a semantic swamp"88 of advertising regulations, the FTC may also be severely curtailing advertising creativity. If nonrational advertisements as well as attempts to create artificial product distinctions and claims of uniqueness were proscribed, advertising could becoine a burdensome endeavor, were it to survive at all. If the FTC's power is unlimited after Pfizer, the Wall Street law office may even replace Madison Avenue as the creative center of advertising.

\section{Problems in the Implementation of Pfizer}

\section{The Advertising Substantiation Program}

Although the FTC has sought to strengthen its formal enforceinent procedure, informal proceedings still account for the vast majority of the FTC's workload. ${ }^{89}$ The most important of these informal programs relating to the reasonable basis doctrine has been the advertisement substantiation plan-typically challenging the product claims of an entire industry at one time ${ }^{90}$ - which demands

rule like that. I think we have to rely in the long run on the good sense of consumers in resisting those kinds of appeals, or at least insisting on some hard evidence of price and quality when they purchase the product. Pitofsky Interview AA-5.

87. See BisHop 111-12; Thain, supra note 79, at 488-89.

88. Austern, What is "Unfair Advertising"? 26 FOOD DRug CoSM. I.J. 659, 667 (1971). See Thain, supra note 9, at 621-22.

89. Since the costs of litigation exceed the costs of negotiating voluntary compliance, the FTC settles most cases short of adjudication. ABA REPORT 22. Aside from the more traditional weapons of informal comphance, the ability of the FTC to negotiate favorable dispositions-especially under the consent order procedure, 16 C.F.R. $\$ \S 2.31-.35$ (1972), promulgated pursuant to 15 U.S.C. $\S 45$ (1970)-should not be underestimated. Given the increasing power the Commission has assumed, large corporations in the future will be making frequent reappearances. In 1972 each of the proposed respondents in the analgesics cases was also challenged by the FTC for other totally unrelated activity. Thus, given the practicalities of the situation, corporations will want to emphasize cooperation and may be willing to make tradeoffs in certain areas in order to maintain a close working relationship with the FTC staff.

90. E.g., 570 BNA ANTtTrust \& Trade Reg. ReP. A-9 (1972) (soap and detergent products); 548 BNA Antitrust \& Trade Reg. ReP. A-8 (1972) (cold 
that written substantiation for advertisement claims be submitted to the FTC upon request.91 As originally envisioned, the plan's primary purpose was educational - to provide the consumer with information he would otherwise not get and thus to facilitate rational product choices. ${ }^{92}$ Paralleling the Pfizer decision, the plan's secondary purpose was to encourage advertisers to substantiate their claims before making public representations. ${ }^{93}$ This function assumed that individuals and consumer groups would study the documenting evidence and exert economic pressure on derelict manufacturers. ${ }^{24}$ Therefore, to protect its good will, each manufacturer would adopt more stringent prior substantiation procedures.

Advertising substantiation has not been successful. Despite the FTC's assertion that advertisers have "tightened their policies," it is apparent the plan has not fulfilled its purposes. The Commission has reported that the first four industries imvestigated-the makers of automobiles, air conditioners, television sets, and electric shavers-responded with volumes of data, but admitted that two-thirds of the information was either questionable or too technical to understand. ${ }^{96}$ The makers of cold remedies delayed the release of their

and cough remedies); 544 BNA ANTTrRUST \& TRADE REg. Rep. A.9 (1972) (toothpastes and dentifrices); 527 BNA ANTITRUST \& TRADE REg. REP. A-20 (1972) (air conditioners and electric shavers); 517 BNA ANTITRUST \& TRADE REG. REP. A-1 (1971) (automobiles). The substantiation requirements are not applied to random claims; and the FTC cannot, of course, evaluate all claims made for all products. Rather, a preliminary determination is necessarily made by the FTC staff as to which questionable representations reach the widest audience.

91. The new requirement not only was expected to assist consumers in making a rational choice among competing claims, but also was intended to increase competition by allowing small competitors to report and thus deflate the unsubstantiated claims of large advertisers. "[T] he companies making superior products [wouldl thus be able to get their messages across." Summary of Remarks by Robert Pitofsky, Director of Bureau of Competition, 517 BNA ANTITRUST \& Trade REo. REP. A-1 (1971).

92. 5 TRADE REG. REP. If 50,135, at 55,220 (1972) (FTC Bureau of Consumer Protection Report on the advertising substantiation program to aid in the debate on the proposed Truth-in-Advertising Bill, S. 1461, 92d Cong., 1st Sess. (1972)); FTC Resolution, reprinted in 517 BNA ANTITRUST \& TRADE REG. REP. D-1 (1971) (requiring submission of special reports relating to advertising claims).

93. Address by FTC Chairman Kirkpatrick Before the Consumer Federation of America, reprinted in 548 BNA ANTITRUST \& Trade Reg. Rep. A-26 (1972).

94. $1 d$.

95. Statements by Robert Pitofsky, reprinted in 592 BNA ANTITRUST \& Trade REG. REP. A-12 (1972). See also Pitofsky Interview AA-2.

96. FTC Staff Report, reprinted in part in 574 BNA ANTITRUST \& TRADE REG. REP. A-14 (1972). In December, 1972, the Institute for Public Interest Representation at the Georgetown Law Center released an exhaustive study of the substantiating evidence for the claims made by television set manufacturers. 
substantiation reports for almost a year, with the foreseeable result that no one would bother to check substantiation data for an old advertising campaign. ${ }^{97}$ But the advertisers need not have resorted to such obfuscatory techniques because few people even read the reports. ${ }^{98}$

Rather than abolish the advertising substantiation plan, the FTC has expanded it. ${ }^{99}$ Furthermore, by utilizing the information submitted to build its cases, the Commission's recently-issued reasonable basis complamts against automobile ${ }^{\mathbf{1 0 0}}$ and air conditioner

Thirty-two of the fifty-nine target claims selected by the FTC were found not to have been adequately substantiated; fourteen of the remaining claims involved standard features available on all models. Apparently only four claims' were passable. Institute for Public Interest Representation Report, reprinted in part in 591 BNA ANTItrust \& Trade Reg. Rep. A-10 (1972). For an excellent example of how a competitor can utilize these studies to educate the consumer and to deter future reasonable basis violatious, see NEwSwEEk, Feb. 12, 1973, at 41, where an advertisement, based on the Institute's study, is entitled "SONY. NO BALONEY." Earlier Sony color television advertisements were among the four substantiated claims that "contained reliable information about unique features which the consumer could use in the choice of a television." Id.

97. See 593 BNA ANTITRUST \& TRADE REg. REP. A-1 (reluctance to publicize trade secrets was ostensibly the cause of delay).

98. 5 Trade REg. REP. If 50,135, at 55,220 (1972) (Bureau of Consumer Protection Report on the advertising substantiation program to aid in the debate of the proposed Truth-in-Advertising Bill, S. 1461, 92d Cong., 1st Sess. (1972)). In addition to this lack of interest, or possibly because of it, in the program's first year no one outside the FTC was able to call attention to gaps in any substantiation report that were not previously found by the FTC staff. However, public interest groups, academicians, and several journalists had "expressed interest." 5 TRADE REg. REP. If 50,135, at 55,220 (1972). If at least this level of interest can be maintained, the program may have some positive impact. See note 96 supra.

99. The FTC recently decided to conduct a supermarket survey of retail food prices, in order to encourage truthful advertising claims and to aid the grocery shopper in making rational product choices. This "informational" program will examine chain-store pricing of 50 to 100 selected common items, within specified metropolitan areas. 596 BNA ANTITRUST \& TRADE REG. REP. A-1 (1973).

Although the FTC intends to continue the program, the Commission has moved it into a "second generation" to deal with some of these problems. The demands by the FTC will emphasize major selling themes instead of particular advertising claims and will also require a summary of the documentation in "plain language" in order to encourage consumers to examine the material. News Conference Held by Robert Pitofsky, Director of FTC Bureau of Consumer Protection, reprinted in part in 593 BNA ANTITRUST \& TRADE REg. REP. A-1 (1972). Pending an assessment of this revitalized program, the FTC will continue to oppose the Truth-in-Advertising Bill, S. 1461, 92d Cong., 1st Sess. (1972), which would substitute the requirement that advertisers provide individual consumers with substantiation at the cost of duplication and mailing. Id.

100. The complaints against General Motors for its claims that "Vega is the best handling passenger car ever built in the United States" and "the chassis of the Buick Opel never needs lubrication" alleged only that the advertiser lacked a 
manufacturers ${ }^{101}$ have gone beyond the purposes of the plan as originally outlined..$^{102}$

prior reasonable basis for the claim. General Motors Corp., 3 TRADE REG. REP. II 20,183, at 22,163 (FTC Dec. 11, 1972).

101. The FTC has lodged complaints against advertising Fedders air conditioners' unique reserve cooling power; Rheem air conditioners' quietest, most efficient system, "revolutionary" in its continual refreshing of inside air; and Whirlpool air conditioners' substantially greater initial cooling capacity. In addition to the reasonable basis charge, these complaints alleged that the representations were false, misleading, and deceptive. Fedders Corp., 3 TRADE REg. REP. II 20,120, at 22,102 (FTC Oct. 12, 1972).

102. Applying sanctions, with the possibility of criminal penalties, on the basis of the submitted information, raises an interesting fifth amendment question. Although the FTC has all but ignored its power to seek criminal penalties, NADER REPORT 64, 194, there are criminal provisions in many of the statutes entrusted to FTC enforcement. Sections 12 and 14 of the FTCA contain the provisions most important for advertising. 15 U.S.C. $\$ 54$ (a) (1970).

Although a "required records" exception to the self-incrimination clause has long been recognized in order to effectuate administrative regulations, the Supreme Court has placed limitations on the exception. An administrative information requirement must be "essentially regulatory" to avoid constitutional review. Grosso v. United States, 390 U.S. 62 (1962). Whereas statutes directed at the general public, Galven v. Superior Court, 70 Cal. 2d 851, 866-69, 76 Cal. Rptr. 642, $652-53,452$ P.2d 930, 940-41 (1969) (gun registration ordinance), or at a group "numbering in the millions," California v. Byers, 402 U.S. 424, 430 (1971) (hitand-run statute), have met the "essentially regulatory" test, statutes directed at "highly selective group[s] inherently suspect of criminal activities" have not. Haynes v. United States, 390 U.S. 85 (1968) (federal gun registration statute); $c f$. California v. Byers, 402 U.S. 424, 469 (dissenting opmion). The advertisement substantiation requirement, clearly aimed at a select group, falls somewhere in between. Should the information program not be "essentially regulatory," advertisers might argue that there existed a substantial hazard of self-incrimination which outweighed any genuine need for the data. Unless the FTC could grant formal immunity from prosecution in exchange for compliance, see Organized Crime Control Act, 18 U.S.C. $\$ 6004$ (1970), or unless the Supreme Court eventually imposed a use restriction, see California v. Byers, 402 U.S. 424, 442-58 (concurring opinion), the substantial hazard of possible criminal penalties might be enough to extend fifth amendment protection to advertisers and permit them to withhold advertising substantiation data.

This would in effect create two separate regulatory schemes-one for individuals and partnerships and one for corporations-since there is no corporate fifth amendment privilege to protect corporate records. E.g., George Campbell Painting Corp. v. Reid, 392 U.S. 286 (1968); Hyster Co. v. United States, 338 F.2d 183 (9th Cir. 1964). Sce also Wild v. Brewer, 329 F.2d 924 (9th Cir. 1964) (even where the sole shareholder was attempting to prevent the introduction of documents, the privilege was not applicable). However, the fifth amendment can have little practical effect on the FTC, unless the individual officers are subject to liability. See Curcio v. United States, 354 U.S. 118, 125 (1957); Smith, The Incredible Electrical Conspiracy, ForTune, April, 1961, at 132-37, May, 1961, at 161-64 (where top corporation executives were forced to serve short prison terms for price-fixing activities on behalf of the corporation). Because large corporations are responsible for most nationally regulated advertising, the fifth amendment has as yet posed no serious barrier to FTC substantiation demands. 
Problems of Enforcing the Standard: The Need for a Suitable Remedy

Assuming the FTC can satisfy the burden of showing that a particular claim was made without a reasonable basis, ${ }^{103}$ effective remedies inust be devised before the new doctrine can have serious impact on advertisers. ${ }^{104}$ The unfairness that must be remedied in these cases is not the deception of or direct injury to consumers, but rather the imposition on consumers of the economic risk that the product might not perform as advertised. ${ }^{105}$ The injury occurs at the time of sale; the remedy, therefore, must focus on the method of marketing and not on the future performance of the product.

Cease-and-desist orders. The cease-and-desist order seems inappropriate to remedy a reasonable basis violation. If the order prohibits a claim only until the advertiser can produce substantiation under the reasonable basis test, the violator can still delay his substantiation tests until after the claim is challenged-thus defeating the purpose of a prior reasonable basis requirement. Furthermore, the cease-and-desist order, as a reinedy in the nature of an injunction, provides no real sanction for the first offense. ${ }^{108}$ However, an advertiser who ignored a final order conceivably would be subject in the future to civil or even criminal penalties. ${ }^{107}$

On the other hand, if the order is framed to prohibit the representation altogether, the refusal to consider post-advertisement substantiation becomes more significant. ${ }^{108}$ If the belated documentation substantiating the claim is held to be irrelevant, the cease-and-

103. Under the reasonable basis test, as under the test for deception, "substantial evidence" is required to insulate the Commission's fact-finding from judicial review. "Substantial evidence is more than a mere scintilla. It means such relevant evidence as a reasonable mind would accept as adequate to support a conclusion . . . . It excludes vague, uncertain, or irrelevant matter." Carlay Co. v. FTC, 153 F.2d 493, 496 (7th Cir. 1946) (reversing FTC ruling that "Ayds" candy did not lead to "easy" weight reduction without a starvation diet). It is clear, however, that what is "uncertain" matter in a deception or falsity case would not necessarily be excludable in a reasonable basis case.

104. See notes 13-16 supra and accompanying text.

105. Pfizer, Inc., 3 TRADE REG. REP. II 20,056, at 22,029 (FTC July 11, 1972); see FTC v. Colgate-Palmolive Co., 380 U.S. 374, 388 (1965).

106. All the general criticisms of the cease-and-desist order are equally applicable here. See note 13 supra.

107. 15 U.S.C. $\$ 45(l)$ (1970) (civil sanction of up to $\$ 5000$ per day per violation). See note 13 supra. In the area of food, drugs, and cosmetics, criminal penalties can theoretically be sought against the violator. 15 U.S.C. $\$ 54(a)$ (1970).

108. See, e.g., Pfizer, Inc., 3 Trade Reg. Rep. If 20,056, at 22,031 (FTC July 11, 1972); H.W. Kirchner, 63 F.T.C. 1282, 1295 (1963). 
desist order not only fails to remedy the initial wrong, but may also extend beyond the FTC's negative function of preventing falsity and fraud; ${ }^{109}$ for the claim, even though it shifts economic risks to the consumer, may still be true. Once the claim is proved true, so that in fact no injury to the consumer has resulted and the economic risk has been dissipated, a permanent cease-and-desist order does not protect the consumer except for its deterrent effect on future unsubstantiated claims. Whether that possible effect by itself will justify a harsh permanent cease-and-desist order is questionable.

Corrective advertising. Many of the shortcomings of the cease-and-desist order procedure have been alleviated by the Commission's imcreasing reliance on corrective advertising. ${ }^{110}$ Despite mitial setbacks in its corrective advertising efforts, ${ }^{111}$ the FTC continues to draft proposed corrective advertising orders. The typical order requires twenty-five percent of the product's advertising over

109. See Alberty v. FTC, 182 F.2d 36, 39 (D.C. Cir. 1950); FTC v. Sterling Drug, Inc., 215 F. Supp. 327, 332 (S.D.N.Y. 1963), aff'd, 317 F.2d 669 (2d Cir. 1963). In ruling on the FTC's request for a preliminary injunction of certain analgesic advertisements, the district court in Sterling Drug held that "[i]f the advertisement is not false, defendants have a constitutional right to utilize it even though its content and blatancy may annoy both the Commission and the general public." $215 \mathrm{~F}$. Supp. at 332.

Even when the representation has been held to be false, the courts have not granted the FTC the power to prohibit the claim altogether if it might at some future time be truthful. Cotherman v. FTC, 417 F.2d 587 (5th Cir. 1969) (order prohibiting the advertising of loan terms which were in fact not offered was modified because the terms might be offered in the future); FTC v. Civil Serv. Training Bureau, 79 F.2d 113 (6th Cir. 1935) (FTC order prohibiting a correspondence school from representing there were government jobs available for its graduates was modified because there might be such jobs in the future). Contra, Century Metalcraft Corp. v. FTC, 112 F.2d 443 (7th Cir. 1940).

110. See Pitofsky Interview AA-3 (characterization of corrective advertising as the "only really effective remedy for advertising excesses").

For cases where the FTC has proposed corrective advertising, see Sanford Levinson, 3 Trade Reg. Rep. I 20,080, at 22,050 (FTC Aug. 16, 1972); Sugar Ass'n, 3 TRADE REg. REP. If 19,857, at 21,872 (FTC 1971); Wamer-Lambert Pharm. Co., 3 Trade Reg. Rep. If 19,838, at 21,859 (FTC 1971); Amstar Corp., 3 TRADE REG. REP. I 19,696, at 21,742 (FTC 1971); ITT Continental Baking Co., 3 Trade Reg. Rep. If 19,681, at 21,727 (FTC 1971). See also Note, supra note 13.

111. See ITT Continental Baking Co., 3 TRADE REg. REP. If 20,182, at 22,162 (FTC 1972). In ITT Continental, the hearing examiner rejected the staff's first contested proposed order requiring corrective advertising, although the examiner dismissed on the ground that the staff had not proven falsity or deception by showing sufficient potential impact on consumers. The FTC had regarded this litigation against the makers of "Wonderbread" as a test case for corrective advertising. Pitofsky Interview AA-3. See also Firestone Tire \& Rubber Co., 3 TRADE REg. REP. If 20,112, at 22,077 (FTC Sept. 22, 1972) (opinion modified Feb. 16, 1973), where the FTC rejected the corrective advertising order sought by a student consumer interest group. 
a stated period (usually one or two years) to carry an FTC-approved retraction designed to dispel the continuing residual effects of the unfair claim. ${ }^{112}$ Recently the Commission obtained its first signed consent order ${ }^{113}$ requiring a seller of swimming pools to devote twenty-five percent of his advertisements for one year to informing the public that the FTC had questioned his practices. ${ }^{114}$ The Commission has also held that it could compel a violator to buy corrective advertising, whereas previously the advertiser had the theoretical option of not advertising at all for that year. ${ }^{115}$ Should the FTC compel advertisers to purchase space or time devoted to warning the public that they were being treated as guinea pigs for untested products, corrective advertising would becolne a powerful weapon against reasonable basis violations.

Counteradvertising. Another innovative remedy considered by the FTC is counteradvertising--short free advertisements sponsored by competitors or special interest groups. Counteradvertisements respond to commercials raising controversial issues of public importance, rebut advertising claims raising controversial scientific conclusions, and inform consumers of important negative ramifications which the challenged advertisement ignored. ${ }^{118}$ Counteradvertising has yet to be tested in the courts; it has been heavily criticized both by the White House ${ }^{117}$ and by the Federal Communications Commis-

112. See, e.g., Sterling Drug, Inc., 3 Trade REG. REP. If 19,925 , at 21,937 (FTC 1972) (requiring "Lysol" manufacturers to include statements that "Lysol" will not reduce colds or flu, after Sterling had made the impliedly deceptive claim that "Lysul" disinfectant "kills gernns on environmental surfaces," with the knowledge that such surface germs did not cause either flu or colds); American Home Prods., 3 TRADE REg. ReP. II 19,962, at 21,984 (FTC 1972) (proposed currective order for a reasonable basis violation-aspirin manufacturers claiming their products would relieve nervous tension and the stresses of everyday life).

113. Proposed complaints notify the respondent not only of the charges against him but of the forn the proposed order would take. 16 C.F.R. $\$ 2.31$ (1972). Within ten days after the service of the complaint, respondent has the option of disposing of the proceeding by a consent order, id. $\S 2.32$, which in effect means the respondent will agree to comply with the FTC's proposed order without further adjudication on the merits. If the respondent refuses to accept a consent order, a formal complaint usually follows. Id. $\S \S 2.21-35$.

114. Sanford Levinson, 3 TrADE Reg. Rep. If 20,080, at 22,050 (FTC 1972).

115. Sugar Ass'n, 3 Trade Reg. Rep. If 19,857, at 21,872 (FTC 1971) (a trade association, with no commercial necessity to advertise during the time the corrective order would be in effect, was compelled to advertise to dispel the deception of past advertisements).

116. Address by FTC Chairman Kirkpatrick, supra note 93, at A-27. But see Alberty v. FTC, 182 F.2d 36 (D.C. Cir. 1950) (if a controversy exists over the worth of a product, a positive advertising claim need not mention the equally credible opposite conclusion).

117. Clay Whitehead, Director of the White House Office of Telecommunications Policy, responded to then FTC Chairman Kirkpatrick's counteradvertising 
sion, which would presumably carry the responsibility of administering any counteradvertising program. ${ }^{118}$ Nevertheless, under the new FTC scheme of regulation, counteradvertising would often be appropriate, particularly in situations similar to the headache remedies cases where claims are based on unproven scientific premises. ${ }^{110}$ If such a program were workable, the Commission could allow the tested but unproven statement to be communicated through advertisements while giving the consumer access to "contrary ideas."120 The combination of an advertisement and a counteradvertisement would permit consumers to make their own choice and might facilitate product comparisons. Moreover, the threat of counteradvertising could deter an advertiser from making unsubstantiated, unqualified claims.

The FTC has already negotiated with the National Broadcasting Company for free counteradvertising time for a farin lobby's rebuttal to a railroad association's paid endorsement of the Surface Transportation Act. ${ }^{121}$ However, commercial advertising of consumer goods was not involved in this negotiation. The economics and inechanics of any program encompassing product counteradvertisements might be so coinplex as to be unmanageable and counterproductive. Determining from among many competitors and consumer groups who may rebut and deciding what controversial material requires refutation may be insurmountable problems.

proposal with a scathing indictment of what Whitehead termed the FTC's attempt to kill the "goose [that is, advertising] that lays the golden egg." Address by Mr. Whitehead, reprinted in 551 BNA ANTrtrust \& Trade Reg. ReP. A-19, A-20 (1972).

118. The FCC's duties would stem from its role in enforcing the faimess doctrine, upheld in Red Lion Broadcasting Co. v. FCC, 395 U.S. 367 (1969), which imposes an affirmative obligation on broadcasters to provide reasonable amounts of time for the consideration of conflicting views on "public issues." Report on Editorializing by Broadcast Licensees, 13 F.C.C. 1246, 1247 (1949). In Banzhaf v. FCC, 405 F.2d 1082 (D.C. Cir. 1968), the court upheld an FCC determination that commercial cigarette advertising, despite its nonrational format, vas controversial speech on a "public issue;" hence broadcasters were required to present a reasonable number of antismoking messages in order to satisfy the pressing public need for "an abundant and ready supply of relevant information." Id. at 1089.

119. See Address by Robert Pitofsky, reprinted in part in 558 BNA ANTrTRUST \& TRADE REg. ReP. A-23 (1972).

120. $1 d$.

121. The American Association of Railroads, in what the farmers termed a "highly propagandistic" presentation, urged viewers to support the proposed Surface Transportation Act, H.R. 12,209, 92d Cong., 1st Sess. (1971). The farm coalition argued that passage would permit the railroads more easily to abandon track in rural areas and that tax increases, service reductions, and "outrageous government handouts" would inevitably result. See 560 BNA ANTITRUST \& TRADE REg. REP. A-28 (1972). 
At the present time, the FTC has received little cooperation in expanding this program beyond the voluntary network negotiations; and some advertisers have threatened to cease advertising on network television rather than submit to counteradvertisements. ${ }^{122}$ Nevertheless, in combination with a prohibition against nonrational entertainment advertisements, ${ }^{123}$ counteradvertising would seein to be an effective means of upgrading informational advertising. ${ }^{124}$

Strict enforcement of the prior reasonable basis doctrine may not be justified. ${ }^{125}$ If the truth of a claim is "discovered," whether by subsequent testing or sustained consumer use, or if the claim has a reasonable basis at the time of the order, there are no lingering effects of the violation that require corrective advertising or any other remedy. ${ }^{126}$ Any sanction then imposed would be punitive, contrary

122. 558 BNA ANtTtrust \& Trade Reg. Rep. A-23, -24 (1972) (statements by broadcasting company and advertising agency executives).

123. See notes 83-87 supra and accompanying text.

124. The FTC has also experimented with requiring refunds to unsatisfied customers. See note 16 supra. In cases where a reasonable basis has not been established prior to the framing of the order, the FTC could justify this remedy as the most effective means of removing the economic risk.

Injunctions might also be useful. Although the FTC's injunction-seeking powers, 15 U.S.C. $\$ 53($ a) (1970), are specifically limited to preventing the false advertising of "food, drugs, devices, or cosmetics", 15 U.S.C. $\$ 52$ (1970), the FTC has not interpreted this limitation strictly. Thus, the FTC sought to enjoin the dissemination through the mail of free sample razor blades; the temporary injunction was thought to be necessary in order to prevent consumer injuries from an impending second mailing. The FTC's theory looked behind the words of the act to interpret the provision's purpose as the protection of consunners from imminent, irreparable harm. However, the Commission obviated the need for the courts to pass on the injunction request by simultaneously arousing enough public opinion to convince Philip Morris to delay voluntarily the second mailing. Philip Morris, Inc., 3 TrADE ReG. ReP. I 20,153, at 22,141 (FTC Dec. 1, 1972).

The temporary injunction would seem to have little chance of acceptance where only the possibility of economic risk was at issue. See FTC v. Sterling Drug, Inc., 317 F.2d 669 (2d Cir. 1963).

125. The advertising substantiation program, as well as Pfizer, was fashioned to enable consumers to distinguish between the seller who is advertising truthfully and one who is unfairly representing that he has proof when in fact the proof is inadequate. FTC's Resolution Requiring Subinission of Special Reports Relating to Advertising Claims, reprinted in 517 BNA ANTITRUST \& TRADE REg. REP. D-1 (1971). But this distinction may be impossible, because true claims can often be made with inadequate substantiation.

126. However, the Commission may avoid admitting such a result by dismissing the accompanying false advertising charge with the statement that the FTC merely failed to discharge its burden of proof, See Pfizer, Inc., 3 TRADE REg. REP. If 20,056, at 22,039 (FTC July 11, 1972).

In an interesting case decided in 1961, advertising claims for a coupling pipe which would "condition" and remove harmful elements from water could not have had a prior reasonable basis under any standard. Nineteen experts testified for the FTC that, by nearly unanimous scientific opinion, a coupling pipe could not 
to the overall truth-seeking function of the FTC, and thus beyond the FTC's power. ${ }^{127}$ Perhaps such punitive attacks are an inevitable consequence of shifting from an objective true-false determination to an examination of the advertiser's decision-making process. However, prior substantiation should not be an end in itself but only a technique to aid the information and truth-seeking functions of the FTC, which in turn enable consumers to make rational product choices. Furthermore, there is the pressing danger that coerced substantiation, in its attempt to raise the overall level of truthfulness, may be evaded by a reduction in the informational content of advertisements, ${ }^{128}$ a strategy which would actually undermine the ultimate goal of rational product choices.

\section{First Amendment Conflict}

The seeming imcongruity of prohibiting true statements sug. gests an examination of the scope of first amendment protection. Although "free speech" protection has not yet been extended to commercial advertising, ${ }^{129}$ certain paid advertisements-especially truthful product comparisons-arguably merit this protection..$^{130}$ The FTC's proposal to apply the fairness doctrine to commercial representations ${ }^{131}$ indicates that the Commission has accepted the underlying premise of this argument-namely that informative advertisements discussing the relative quality of consumer goods raise controversial issues of public importance. ${ }^{132}$ In New York Times $v$.

affect water in the manner alleged. Nevertheless the respondent paraded ninetyone satisfied users of the water conditioner, "guinea pigs" who had assumed the economic risk; and the court reversed the FTC. Evis Mfg. Co. v. FTC, 287 F.2d 831, 847 (9th Cir. 1961).

127. See Keele Hair \& Scalp Specialists, Inc. v. FTC, 275 F.2d 18, 23 (5th Cir. 1960); Menzies v. FTC, 242 F.2d 81 (4th Cir.), cert. denied, 353 U.S. 957 (1957); Alberty v. FTC, 182 F.2d 36, 39 (D.C. Cir. 1950); Hearings on $S$. 3744 , supra note 20 , at 5 (statement of Commissioner Davis), reprinted in Dunn, supra note 20, at 366; Note, supra note 13, at 491; cf. Thain, supra note 9 , at 625-26 (the author sees the remedies not as punitive but as a part of an educational process whereby businessmen will learn to maximize profits and public benefits).

128. See notes 83-88 supra and accompanying text.

129. Breard v. City of Alexandria, 341 U.S. 622, 642-43 (1951); Murdock v. Pennsylvania, 319 U.S. 105, 110-11 (1943); Valentine v. Chrestensen, 316 U.S. 52 (1942); Redish, supra note 8, at 450-57.

130. Redish, supra note 8, at 443-48; Comment, Psychological Advertising, supra note 79 , at 1121; Comment, supra note 80 , at 187 . See generally Meiklejohn, The First Amendment Is an Absolute, 1961 Sup. CT. Rev. 245.

131. See notes $116-18$ supra and accompanying text.

132. Compare Counteradvertising Proposal by FTC Chairman Kirkpatrick, reprinted in 548 BNA ANTTTRUST \& TRADE REg. REP. A-27 (1972) with Redish, supra note 8, at 434-48. Sce also Sam Morris, 11 F.C.C. 197, 198 (1946), 
Sullivan, ${ }^{133}$ the Supreme Court stated that the "debate on [such] public issues should be uninhibited, robust, and wide-open." Although Times was a private libel action, the first amendment has since been extended to protect not only all "newsworthy" comment, ${ }^{134}$ but also all matters in which the public has a legitimate interest. ${ }^{135}$ Furthermore, the limits of this expanding protection are not yet in sight. ${ }^{136}$ Thus, respondents who obtam substantiation after their advertising claim may have a legitimate first amendment defense to the reasonable basis coinplaint. ${ }^{137}$

\section{THE NeEd for a Reasonable Basis Requtrement}

\section{Overlap with Existing Programs}

Aside from the sizable enforcement problems, it is unclear as a matter of policy whether the benefits of the Pfizer reasonable basis doctrine are worth the costs. Arguably, the reasonable basis doctrine is unnecessary since there is a considerable overlap with the traditional deception charge. If it is assumed that the FTC cannot prove the advertising clain lacked prior substantiation, the claim may still be false and misleading and, therefore, unfair by conventional standards. Although the standard propounded by the aspirin cases in effect would decide the true-false question, ${ }^{138}$ proving a claim false and misleading in some instances may be easier than showing that no reasonable basis for the claim existed. ${ }^{139}$

where the FCC argued that the fairness doctrine extended to commercial representations that raise "basic and important social, economic, or political issues."

133. 376 U.S. 254 (1964).

134. Time, Inc. v. Hill, 385 U.S. 374 (1967).

135. See Pickering v. Board of Educ., 391 U.S. 563 (1968).

136. See St. Amant v. Thompson, 390 U.S. 727, 730-31 (1968).

137. One court has already stated that "[i]f the advertisement is not false, defendants have a constitutional right to utilize it . . . FTC v. Sterling Drug, Inc., 215 F. Supp. 327, 332 (S.D.N.Y. 1963), aff'd, 317 F.2d 669 (2d Cir. 1963), discussed in note 109 supra.

138. See note 75 supra and accompanying text.

139. Tests by both the manufacturer and the FTC conducted any time are relevant to the false and misleading question. Against allegations of falsity, the advertiser is not restricted to information that he actually used in his marketing decision, but may introduce information that he might have used. In lieu of evaluating the thought processes of the marketing decision-maker, the charge of deception or falsity focuses on the mind of the consumer: a claim is deceptive if, with respect to the intended audience, it las the "capacity" to mislead. E.g., Gelb v. FTC, 144 F.2d 580 (2d Cir. 1944), where an advertisement for "permanent" hair coloring was held deceptive, even though the prosecution's wituess had not herself been deceived; Pfizer, Inc., 3 TRADE REG. ReP. If 20,056, at 22,031 (FTC July 11, 1972); Gellhorn, supra note 13, at 562. In testing the impact of a statement on consumers, the deduction a "reasonable man" would make is not conclusive. 
On the other hand, recent developments have reduced the overlap between reasonable basis complaints and deception charges. ${ }^{140}$ Formerly, when purchasers believed that manufacturers substantiated their claims, ${ }^{141}$ the deception charge might have covered reasonable basis cases. But deception complaints are becoming very difficult to prove since the typical consumer and even susceptible groups such as children no longer expect absolute truth in advertising. ${ }^{142}$ However, to permit advertisers to defend false claims on the ground that no one believes them would seriously erode the consumer protection role of the FTC. Hence the new reasonable basis standard may have been adopted in part to encourage consumer awareness and to enable the FTC at the same time to maintain a strong regulatory scheme.

\section{Practical Advantages}

Although most complaints issued against advertisers for claims having no reasonable basis are likely to be joined with charges of deception or falsity, ${ }^{143}$ the Pfizer standard is advantageous to the

The FTC has the responsibility for protecting not only the gullible and foolish. E.g., Charles of the Ritz Distrib. Corp. v. FTC, 143 F.2d 676 (2d Cir. 1944); see Gellhorn, supra note 13, at 562; cf. H.W. Kirchner, 63 F.T.C. 1282, 1290 (1963). It must also protect especially susceptible audiences, such as children, the elderly, and the economically unsophisticated. See generally D. CAPLovitz, THE POOR PAY MORE (1963). Since the inquiry is focused on the group to whom the claim is directed, a demonstration that a susceptible group was the target of the advertisement would increase the chances of finding deception. See Thain, supra note 79 , at $493-95$.

Although one of the reasonable basis factors, the likely degree of consumer reliance, appears to take individual disabilities into account, the FTC has not as yet used this criterion to require a higher degree of prior substantiation. See Pfizer, Inc., 3 TRADE REG. REP. II 20,056, at 22,030 (FTC July 11, 1972).

140. Nevertheless, in many cases the FTC will find it easier to prove no reasonable basis for the claim than to prove an advertisement false or deceptive. Because the burden of coming forward with evidence has been shifted, the FTC need only consider the information actually utilized by the advertiser at the time of the claim, thus limiting a full-scale battle of the experts. If the analgesics complaints are upheld, the contradictory testimony of one or two credible experts might even be enough to support a section 5 violation.

141. See H.W. Kirchner, 63 F.T.C. 1282, 1295 (1963); Travers 554. As late as the mid-1960's, most consumers utilized advertising as the major source of product information, since the individual seemingly did not incur any marginal increased cost by doing so. Advertising was generally believed to be accurate. R. Bauer \& S. Greyser, Advertising in America: The Consumer View 330-33 (1968) (consumer poll).

142. In dismissing the FTC staff complaint in ITT Continental Baking Co., 3 TRADE REG. REP. If 20,182, at 22,162 (FTC Dec. 27, 1972), the hearing examiner found that even five-year-olds did not believe that the essential nutrients in "Wonderbread" accelerated growth.

143. See Fedders Corp., 3 Trade Reg. Rep. If 20,120, at 22,102 (FTC Oct. 12, 1972); note 101 supra. 
prosecution for several reasons. While the reasonable basis charge itself does not shift the Commission's burden of proving a section 5 violation, ${ }^{144}$ it does shift the burden of going forward with the evidence. Where previously the FTC carried the burden of investigating and proving truth, falsity, or deception, the respondent is now required to introduce his prior substantiation; and the FTC's burden is reduced to showing that such evidence is insufficient. ${ }^{145}$ Considerable investigative costs formerly incurred by the FTC are thus shifted to the advertiser where, under the Commission's theory, such costs belonged in the first place. Since investigations usually take up to two years before the issuance of a complaint, ${ }^{146}$ the transfer of this investigative burden could lead to quicker challenges. The delay between an unfair advertising claim and the FTC's fimal order would be shortened. Not only would this free the Commission's resources for other regulatory programs, but also the consumer would receive expedited protection from unsubstantiated, potentially false and misleading advertising claims.

Even though the cost of prior substantiation must eventually be passed on to consumers, the manufacturer, necessarily having accumulated some substantiating data in the production process, is in the best position to perform the investigating function at the least cost to society. ${ }^{147}$ A purchaser can seldom initiate investigations on his own because the costs of an individual inquiry are greater than any possible increased satisfaction he might derive from making the "right" product choice. Aside from automobiles, few consumer purchases are large enough for an effective study by each buyer. ${ }^{148}$

It is arguable that consumers would rather make an occasional "wrong" product choice than pay the added cost of prior substantiation for advertisements. Simce the credibility of advertisers is so

144. See Pfizer, Inc., 3 Trade Reg. Rep. If 20,056, at 22,039 (FTC July 11, 1972); cf. Tashof v. FTC, 437 F.2d 707, 715-16 (D.C. Cir. 1970) (opinion dissenting in part). On the other hand, the shifting of the entire burden of proof has been recommended, despite the constitutional implications of imposing a presumption of guilt. NADER REPORT 165.

145. 585 BNA Antitrust \& TRAde Reg. Rep. B-4 (1972) (analysis of Pfizer).

146. See ABA RePORT 30-32.

147. E.g., Pfizer, Inc., 3 Trade Reg. Rep. If 20,056, at 22,033 (FTC July 11, 1972); BISHOP 183-87. But cf. ABA REPORT 106 (separate statement of Richard Posner):

Just as the cheapest way to reduce the incidence of certain crimes, such as car theft, is by inducing potential victims to take sinuple precautions (locking car doors), so possibly the incidence of certain frauds could be reduced at least cost to society by insisting that consumers exercise a modicum of care in purchasing, rather than placing restrictions on sellers' marketing methods.

148. See Travers 552. 
low, it would not be surprising if many consumers saw Pfizer solely in terms of an across-the-board price rise. On the other hand, consumers arguably have always been paying the equivalent of this incremental cost; all too often the economic risk that a product would not perform as advertised may have become actual economic injury. Thus the requirement of prior substantiation for advertising claims might merely be an attractive technique for spreading the risk among all consumers. Even in the unlikely event that the added cost of prior substantiation approaches the amount of economic loss due to "wrong" product choices, ${ }^{148}$ forced substantiation will at least shift this cost to the relatively rich; this is because the economically disadvantaged are most susceptible to advertising deception and bear a disproportionate share of the present loss, ${ }^{160}$ whereas any price rise would be absorbed by all consuiners. Furthermore, since the importance of advertising and consumer reliance thereon has been - generally recognized, a reasonable basis standard that raised the overall level of truthfulness at little or no cost to society might partially justify present mind-boggling advertising budgets.

\section{CONCLUSION}

The reasonable basis doctrine expands the FTC role far beyond the negative function of preventing falsity and fraud. ${ }^{161}$ To fortify the consumer's "right to be informed,"152 the FTC's new positive approach aims at imcreasing the consumer's ability to make rational product choices. Consumers need no longer rely on the advertiser's "social consciousness" 153 for the proper testing of products. Although the FTC has not yet forced advertisements to become "fountain[s] of relevant information," standard atteinpts to ensure that the offered information will be accurate. In Pfizer, the FTC focused on marketing methods and the imposition of economic risk rather than on product performance and subsequent economic loss, with the expectation that prior substantiation would raise the general level of advertising truthfulness.

Although the FTC has expanded its advertising policing techniques, a thorough investigation in some cases would reveal that claims made without a reasonable basis would also be deceptive

149. See Pitofsky Interview AA-2.

150. See generally D. CAPLOVITZ, supra note 139.

151. See note 127 supra and accompanying text.

152. Message from the President, Consumers' Protection and Interest Program, H.R. Doc. No. 364, 87th Cong., 2d Sess. 2 (1962).

153. BISHOP 140.

154. Id. at 114 . 
or false and misleading. The Commission should still apply traditional standards in those blatant cases where falsity is easy to prove by simply concentrating on the injury to various consumers. Unfortunately, few cases seem to turn on such black and white truefalse distinctions. The reasonable basis test attacks the large gray area where advertising claims are difficult to prove false. By declaring unfair and unlawful all advertising representations made without a prior reasonable basis and by forcing a shift in the burden of bringing forth evidence, the Commission has made section 5 an easier and less expensive law to administer. If the difficulties in applying the test can be overcome, the Commission may finally einerge as an effective regulator of commercial advertising. 
